Chapman University

Chapman University Digital Commons

War and Society (MA) Theses

Dissertations and Theses

Spring 5-2019

\title{
Bill Clinton, George W. Bush, and Immigration Policy: How 9/11 Transformed the Debate Over Illegal Immigration
}

Robert Nelsen

Chapman University, nelse105@mail.chapman.edu

Follow this and additional works at: https://digitalcommons.chapman.edu/war_and_society_theses

Part of the American Politics Commons, Immigration Law Commons, International Relations

Commons, Legislation Commons, President/Executive Department Commons, and the Terrorism Studies

Commons

\section{Recommended Citation}

Nelsen, Robert. Bill Clinton, George W. Bush, and Immigration Policy: How 9/11 Transformed the Debate Over Illegal Immigration. 2019. Chapman University, MA Thesis. Chapman University Digital Commons, https://doi.org/10.36837/chapman.000059

This Thesis is brought to you for free and open access by the Dissertations and Theses at Chapman University Digital Commons. It has been accepted for inclusion in War and Society (MA) Theses by an authorized administrator of Chapman University Digital Commons. For more information, please contact laughtin@chapman.edu. 
Bill Clinton, George W. Bush, and Immigration Policy:

How 9/11 Transformed the Debate Over Illegal Immigration

\author{
A Thesis by \\ Robert B. Nelsen \\ Chapman University \\ Orange, CA \\ Wilkinson College
}

Submitted in partial fulfillment of the requirements for the degree of

MA in War and Society

May 2019

Committee in charge:

Lori Cox Han, Ph.D., Chair

Kyndra Rotunda, J.D.

Gordon Babst, Ph.D. 
The dissertation/thesis of Robert B. Nelsen is approved.

Thesis Defense: May 2019

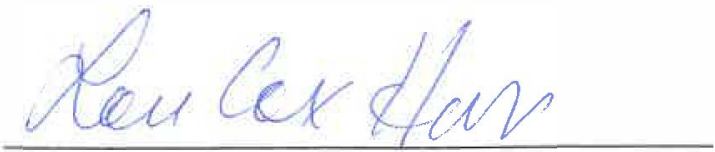

Dr. Lori Cox Han

Committee Chair

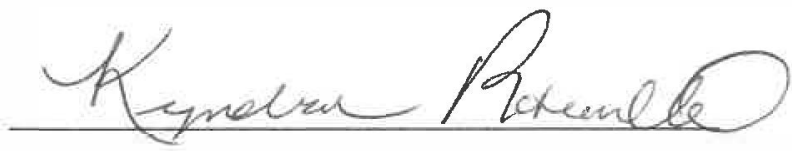

Dr. Kyndra Rotunda

Committee Member

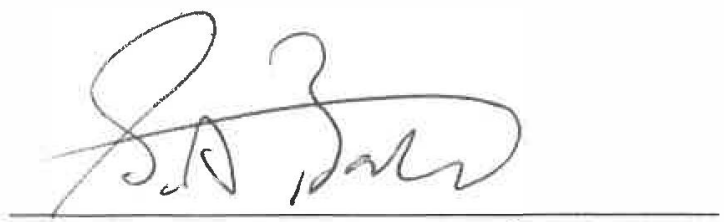

Dr. Gordon Babst

Committee Member 
Bill Clinton, George W. Bush, and Immigration Policy:

How 9/11 Transformed the Debate Over Illegal Immigration

Copyright $@ 2019$

by Robert B. Nelsen 


\begin{abstract}
Bill Clinton, George W. Bush, and Immigration Policy:

How 9/11 Transformed the Debate Over Illegal Immigration

by Robert B. Nelsen
\end{abstract}

Since the terrorist attacks of September 11, 2001, Americans have been at war against some form of terrorism both at home and abroad. This includes abuses of federal immigration laws and policies that relate to legal and illegal immigration with Mexico. It is easily substantiated that thousands of Americans have died at the hands of illegal immigrants from Mexico through criminal activity in the United States or through illegal drug trafficking. This thesis considers whether the immigration policies of Presidents Bill Clinton and George W. Bush were at fault for not properly securing the border prior to these attacks. Specifically, did the Bush administration effectively secure the border following $9 / 11$ ? Furthermore, how does the substantial growth of illegal immigrants from 1995 to 2005 correlate to the failed policies passed during this era? This analysis shows that it should not have taken a catastrophic event like the terrorist attacks on 9/11 to realize the urgent need for stronger national security in the homeland. This work concludes with the argument that both administrations should have placed a greater priority on promoting stronger federal immigration laws and policies that would have resulted in better solutions to permanently secure America's southern border with Mexico. 


\section{TABLE OF CONTENTS}

CHAPTER 1: Introduction

The American Dream: Immigrants in the Early 1900s 4

The Greedy 20's to World War II 6

The Immigration and Naturalization Act of 1965

$\begin{array}{ll}\text { Conclusion } & 11\end{array}$

CHAPTER 2

$\begin{array}{ll}\text { The Border Patrol in the 1990s } & 16\end{array}$

Rhetoric of Immigrants and the Militarization of the Border 20

The Sovereignty Debate - Territorial Jurisdiction 24

Classification of Illegal Immigrants $\quad 28$

$\begin{array}{ll}\text { Conclusion } & 30\end{array}$

CHAPTER $3 \quad \mathbf{3 5}$

Visa Overstay and Statistical $\quad 36$

Operation Gatekeeper- The Death Trap 43

Illegal Immigration Reform and Immigrant Responsibility Act of $1996 \quad 48$

President George W. Bush - The 2000 Presidential Election 53

2001 - Months prior to $9 / 11 \quad 56$

$\begin{array}{ll}\text { Conclusion } & 61\end{array}$

$\begin{array}{ll}\text { CHAPTER } 4 & \mathbf{6 4}\end{array}$

Illegal Immigration following 9/11 Terrorist Attacks $\quad 67$

Anti-Terrorism Act of 2001 and the Patriot Act $\quad 70$

The Enhanced Border Security and Visa Entry Reform Act 74

The Homeland Security Act of $2002 \quad 76$

The Intelligence Reform and Terrorism Prevention Act 78

The U.S. Relationship with Mexico following 9/11 80

Border Patrol and the Secure Border Initiative $\quad 84$

$\begin{array}{ll}\text { Secure Fence Act of } 2006 & 87\end{array}$

$\begin{array}{ll}\text { Conclusion } & 89\end{array}$

CHAPTER 5: Conclusion $\quad 91$

The Damage of Illegal Immigration: Why should it matter? 93

Operation Gatekeeper: What went wrong? 95

IIRIRA of 1999

Immigration Policies 2000-Pre/911 $2001 \quad 100$

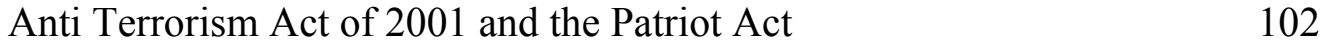

$\begin{array}{ll}\text { The Homeland Security Act of } 2002 & 103\end{array}$

$\begin{array}{ll}\text { Secure Fence Act of } 2006 & 105\end{array}$

$\begin{array}{ll}\text { Illegal Immigration - Final Thoughts } & 106\end{array}$ 


\section{LIST OF TABLES}

Table 1: Estimated Illegal Immigrant Population 1990 and 2000

Table 2: Illegal Immigrants Removed or Returned 41

Table 3: Percentage of Southwest Border Apprehensions 46

Table 4: Country of Birth of the Illegal Immigrant Population 67

Table 5: Removals and Returns 2000 to $2005 \quad 68$ 


\section{CHAPTER 1- Introduction}

When millions of New York City residents woke on a Tuesday morning in early September of 2001, they were thankful to see a clear blue sky rather than storm damage from Hurricane Erin, which had threatened the East Coast during the previous four days. Author George McKenna would later describe in his book, The Puritan Origins of American Patriotism, that the sky on this morning "was not just blue, it was a light, crystalline blue, cheerful and invigorating." ${ }^{1}$ But another storm of monumental consequences was already on its way. It was the morning of September 11, 2001.

Lower Manhattan had warmed to 65 degrees by 8:46 AM when the New York City skies suddenly exploded into the worst terrorist attack on American soil since Pearl Harbor. In a series of unbelievable images, American Airlines Flight 11 was flown directly into the World Trade Center North Tower by Al-Qaeda terrorists, and 17 minutes later, United Airlines Flight 175 crashed into the WTC South Tower. Within two hours both 110-story towers collapsed to kill 2,606 workers, fire fighters, police and visitors. ${ }^{2}$ Two additional hijacked flights in Pennsylvania and Washington D.C. killed hundreds more. These horrific terrorist attacks led to a decade in which more than 6,000 American soldiers were killed in Middle East wars along with several smaller terrorists attacks inside the United States while Congress was vigilant to pass legislation that strengthened previously ineffective visa and border security regulations.

After the September 11, 2001 terrorist attacks on the Twin Towers in New York City, the constant fear of additional terrorist strikes caused a change in how most

\footnotetext{
${ }^{1}$ McKenna, George. The Puritan Origins of American Patriotism. New Haven, CT: Yale University Press, 2007.

2 "Deaths in World Trade Center Terrorist Attacks --- New York City, 2001." Centers for Disease Control and Prevention. Department of Health and Human Services, September 9, 2002. https://www.cdc.gov/mmwr/preview/mmwrhtml/mm51SPa6.htm.
} 
Americans viewed immigrants and prevailing immigration laws and policies. In the months and years following $9 / 11$, it was not uncommon for all immigrants to be stereotyped as potential terrorists regardless of their legal status. In the mid-to-late 1990s, the United States had naively believed that the homeland was safe from foreign terrorism despite an earlier 1993 truck bombing in the garage of the World Trade Center. It took a catastrophic event like the total destruction of the Twin Towers and two additional 9/11 attacks that caused the death of nearly 3,000 innocent lives for all Americans to realize the urgent need for stronger national security. Although it was a horrific time in history, 9/11 forced all Americans to see how dangerous the world had become and why enhanced border security was essential. This meant that all borders and ports of entry needed to be soundly secured, including those with Mexico and Canada. United States security officials had never anticipated terrorists like those responsible for 9/11 to enter the United States through the federal Visa Waiver Program. As a result, future United States laws and policies had to prevent terrorists from entering the United States through abuse of any immigration program or through any port of entry. The southern border between the United States and Mexico was of particular concern because of ongoing crime, drug trafficking, illegal immigration, and easy access for potential terrorists to cross somewhere along the 1,954 miles.

Since the terrorist attacks of 9/11, Americans have been at war against some form of terrorism both at home and abroad. This includes abuses of federal immigration laws and policies that relate to legal and illegal immigration with Mexico. Thousands of Americans have died at the hands of illegal immigrants from Mexico through criminal 
activity in the United States or through illegal drug trafficking. ${ }^{3}$ Therefore, the first question that confounds many who have followed American history is: Why didn't the United States Congress and President Bill Clinton pass immigration laws and implement strong policies and/or executive orders based upon earlier homeland attacks that could have prevented 9/11? And why did President George W. Bush fail to take advantage of the window of opportunity following $9 / 11$ to fully tighten United States immigration laws and permanently strengthen America's southern borders with Mexico during his eight years in office? Throughout the thesis, it will become evident that due to the political environment of the time, Clinton and Bush were more focused on gaining political support than introducing adequate policies. This thesis examines this period in American history -- the presidencies of Clinton and Bush -- and concludes with arguments on why it should have been a greater priority to promote stronger federal immigration laws and policies that would have resulted in better solutions to permanently secure America's southern border with Mexico.

Before analyzing the Clinton (1993-2001) and Bush (2001-2009) administration policies regarding immigration, it is necessary to outline a basic explanation of immigration laws in the United States during the $20^{\text {th }}$ century that eventually led to weakened immigration policies prior to the $9 / 11$ terrorists attacks. Since immigration from Mexico was minimal during the early to mid-1900s, it is more helpful to look at immigration that took place from other countries during this period. Following this brief historical analysis, it is then important to focus on immigration laws and policies along

\footnotetext{
${ }^{3}$ Immigration and Customs Enforcement. Fiscal Year 2017 ICE Enforcement and Removal Operations Report, Fiscal Year 2017 ICE Enforcement and Removal Operations Report $\S$ (n.d.). https://www.ice.gov/sites/default/files/documents/Report/2017/iceEndOfYearFY2017.pdf.
} 
the southern border between Mexico and the United States, starting with the Immigration and Naturalization Act of 1965, but primarily examining the years 1997 through 2009.

The American Dream: Immigrants in the Early 1900s

It was ironic that James Truslow Adams wrote "life should be better and richer and fuller for everyone, with opportunity for each according to ability or achievement" when he popularized the American Dream phrase in 1931. After all, the worldwide Great Depression was in its second year, and it certainly eroded any appreciation for the ethos of the American Dream as a pathway for hard workers to prosper. And this was also true for many new immigrants to the United States during the early 1900s in their struggles to overcome severe difficulties caused by massive urbanization and industrialism. Although business and industry thrived during the early $20^{\text {th }}$ century, except during the Depression, the promises of the American Dream were often a double-edged sword that had enticed millions of immigrants to America but became a nightmare when poor living conditions, corruption, low wages, and unemployment led them to become a new class of urban poor. Instead of an America that fostered acceptance and opportunity, immigrants and rural migrants found cities that manifested prejudice and manipulation. Instead of an America where hard work led to prosperity and success, they found cities where business and political corruption became the pay off. In 1900, only about one-third of people lived in a city with more than 2,500 people. ${ }^{4}$ However, by 1920 , over half of the American population lived in cities. ${ }^{5}$ This rapid rise in the urban population can largely be

\footnotetext{
${ }^{4}$ United States Census Bureau. Population Distribution, Population Distribution, (2003). https://www.census.gov/population/www/cen2000/censusatlas/pdf/2_PopulationDistribution.pdf.

${ }^{5}$ Id.
} 
attributed to immigrants and rural families and their pursuit of the American Dream. Between 1880 and 1910, about 11 million Americans moved from rural areas to the cities. ${ }^{6}$ As the population in cities rapidly grew, so did the problems associated with outof-control urban development. Most cities were unable to deal with the rapid population growth, including the building of adequate sewers and housing along with police stations, fire departments, and schools. It was low wages that forced most working families to live in crime-ridden neighborhoods and overcrowded tenement housing.

Immigrants during this decade and in the several decades to follow traveled to America to pursue their dream of prosperity. However, as hundreds of thousands of immigrants surged to America, living conditions worsened and drove many immigrants back to their homelands. For every 100 immigrants from Europe, 44 went back because they realized that going from "rags to riches" was not possible during the industrialization period. It was during this period that the American Dream seemed the most hollow. ${ }^{7}$

During the progressive era in the early years of the 1900 s, there were many pieces of literature that personified the living conditions for many immigrants who migrated to the United States. One of those was the 1906 novel, The Jungle, by Upton Sinclair, which elaborates on how the promise of the ideals of an American Dream was nothing more than a scam from the corrupt wealthy. In Sinclair's novel, the author narrates how he believes capitalism during this time attacked the values of an American Dream through greed and corruption. The Jungle was just one of many depictions about the poor social and living conditions for immigrants. Novels like Lincoln Steffens' The Shame of the

\footnotetext{
${ }^{6} I d$.

${ }^{7}$ Martin, Susan. A Nation of Immigrants. New York: Cambridge University Press, 2010.
} 
Cities and Ida Tarbell's History of the Standard Oil Company both told similar tales of how immigrants were funneled into poor living conditions. Even in the 1936 silent film, Modern Times, the shallow promise of the American Dream is further personified by factory working conditions during the Great Depression. The opening scenes of the movie show how workers are forced to work at the mace of the machines, which are sped up on numerous occasions because of the greed by the factory owner to produce more goods. This idea of the American Dream has dehumanized people to work in factories and become little more than cogs in a machine.

\section{The Greedy 20's to World War II}

The "Roaring 20s" ought to be known as the "Greedy 20s" as the wealthy class sought to get rich by any means possible. By 1921, more farmers were moving to the cities since prices for corn corps had dropped 77 percent in the preceding two years. ${ }^{8}$ The economy in the cities was beginning to boom as the shift from producing capital goods to consumer goods generated thousands of new jobs. Steel production was in its heyday as it went on to supply the material for the hundreds of thousands of Model-T automobiles. Radios also saw booming increases in sales with 843 million sold alone in $1929 .{ }^{9}$ The American Dream seemed like the real deal until Wall Street corruption brought about the stock market crash in late 1929. While some working conditions in the cities had improved during the 1920s, Prohibition had also created chaos for the immigrant working-class in their pursuit of upward social mobility.

\footnotetext{
${ }^{8}$ United States. Federal Reserve Bank of St. Louis. "Farm Prices of Corn and Fruit", (1924).

9 "Radio: A Consumer Product and a Producer of Consumption." Radio: A Consumer Product and a Producer of Consumption. Library of Congress, 1995.

http://lcweb2.loc.gov:8081/ammem/amrlhtml/inradio.html.
} 
In the novel, Dry Manhattan, by Michael Lerner, the author accurately describes the years leading up to Prohibition in addition to illustrating the problems of enforcing the ban on alcohol sales. Lerner explained how several notable hotels in New York had to close in Prohibition's first year of 1920, which affected the economy but more importantly stripped valuable jobs from the immigrant working-class. Smaller businesses were also affected because they were unable to recoup the lost alcohol sales. This made it difficult for the immigrant working-class because of the lost jobs and declining wages. Another example of greed in the novel was when Prohibition zealot William Anderson disguised his intolerance for the working class and foreigners with his "American" morals. He pitted the ethnic public against white Americans. Anderson portrayed foreign immigrants as threatening to everything genuinely American. Because of the additional social divide created by Prohibition, living conditions were especially difficult for hardworking immigrants trying to support their families. ${ }^{10}$

When Prohibition was enacted, bars were shutdown. Subsequently, immigrant workers did not have a place to relax and drink after a long day of work. Prohibition also created a criminal environment to the already frenzied life style for the working class. The popular 1931 mobster movie, The Public Enemy, shows how unsavory aspirations for the American Dream can also lead to criminal behavior. The two main characters, Tom and Matt, start their life of crime at an early age and later become Prohibition bootleggers in the Chicago underworld. Ultimately, they are killed to demonstrate the consequences of trying to pursue personal gain through crime. ${ }^{11}$

\footnotetext{
${ }^{10}$ Lerner, Michael A. Dry Manhattan: Prohibition in New York City. Cambridge, MA: Harvard University Press, 2008.

${ }^{11}$ The Public Enemy. United States: Warner Brothers, 1931.
} 
With the end of Prohibition in 1933, the United States was in the grips of the Great Depression. Because there were few good paying jobs, it also brought about an ugly period in history that further excluded immigrants from finding employment. This only deepened the segregation and discrimination that was left over from slavery and the Civil War. What has been called the "Discriminatory Century" became more of a reality. Any pursuit to achieve the American Dream was faced with discrimination. Hardworking immigrants were unable to earn a fair wage, regardless of how hard they worked. Immigrants were not hired for high-paying jobs. In order to divide and segregate the population more, the Grandfather Clause was implemented for voting in the southern states. It stated that if your grandfather had voted in the past then you were eligible to vote, which basically eliminated all immigrants from voting. ${ }^{12}$ There was also a question section before voting to "qualify" individuals in their right to vote. However, the difficulty of questions was much harder for immigrants. It was said that this solved the "immigrant problem" and successfully took them out of politics. It was this kind of discrimination that prevented many ethnic groups from having the freedom to achieve prosperity in the American Dream.

As the Great Depression lingered, there were many speed bumps for families trying to pursue the American Dream. With the start of World War II in 1939 in Europe, more industry jobs were created to supply U.S. Allies with weapons. Following the attack on Pearl Harbor in late 1941, the United States declared war on Japan, Germany, and Italy. This fueled the economy for several years and led to a tremendous need for more workers to support the war effort. But the downside of World War II was that nearly

\footnotetext{
12 “Grandfather Clause.” Legal Information Institute. Cornell Law School, June 22, 2015. https://www.law.cornell.edu/wex/grandfather_clause.
} 
400,000 men were killed and over 600,000 were wounded. ${ }^{13}$ This created difficult problems for families since the main wage earner was either killed or wounded. Following the end of the Korean conflict in 1953, the Cold War between the Soviet Union and the United States led to a 30-year period that stymied immigrants' pursuit of the American Dream.

The Immigration and Naturalization Act of 1965

Until the 1960s, the Immigration Act of 1924 placed an immigration limit through the national origins quota. The quota provided immigration visas to each nationality by providing only two percent of the total number of each nationality in the United States based on the 1890 national census. ${ }^{14}$ As the civil rights movement was flourishing in the early 1960s, there was a call to reform immigration policy. President John F. Kennedy began the discussion in June of 1963, calling the quota "intolerable. ${ }^{, 15}$ But following his assassination in November 1963, the discussion moved to Congress, which passed the Immigration and Naturalization Act of 1965 that eliminated the quota. President Lyndon B. Johnson would later falsely claim that the act "is not a revolutionary bill. It does not affect the lives of millions....It will not reshape the structure of our daily lives or add importantly to either our wealth or our power." ${ }^{, 16}$ This was in response to the backlash from those who saw the possibility of immigration getting out of hand.

\footnotetext{
${ }^{13}$ U.S. Department of Commerce. "World War II: 70 Years On." World War II: 70 Years On. ${ }^{14}$ H.R. 2580, 89th Cong. (Jun 30 ${ }^{\text {th }}$, 1968) (enacted).

${ }^{15}$ Ludden, Jennifer. "1965 Immigration Law Changed Face of America.” NPR. NPR, May 9, 2006. https://www.npr.org/templates/story/story.php?storyId=5391395.

${ }^{16}$ Public Papers of the Presidents of the United States: Lyndon B. Johnson, 1965. Volume II, entry 546, pp. 1037-1040. Washington, D. C.: Government Printing Office, 1966.
} 
The legislation that was passed in 1965 marked a change to immigration policy and had a drastic impact for years to come. Instead of the quota, it allowed the government to place preferences on the immigrants who received legal status; for example, preference was given to anyone who had relatives in the United States. The goal of the bill, along with most pieces of immigration legislation, was aimed at the unification of families. In the five years following the bill's passage, immigration from Asian countries more than quadrupled. Due to other Cold War-era conflicts during the 1960s and 1970s, immigration from many communist regimes like Cuba, Eastern European countries, and elsewhere drastically increased. From 1965 to 1995, following the Immigration and Naturalization Act of 1965, the number of immigrants tripled from the preceding 30 years. ${ }^{17}$ During this same period, the highest number of immigrants that came to the United States were from Mexico, with a total of 4.3 million. ${ }^{18}$

Following the Immigration and Naturalization Act of 1965, there was a huge influx of illegal Mexican immigrants flooding the borders. Although for many, the INA of 1965 seemed like the morally right thing to do, it consequently allowed and resulted in thousands of undocumented and dangerous criminal immigrants to live in the United States. Although it is true that many were women and children searching for a more prosperous life, it still opened the door for criminals and expanded drug traffic. It took another 20 years and more than two million undocumented immigrants before the Immigration Reform and Control Act of 1986 was passed. This new act was "passed in order to control and deter illegal immigration to the United States." Its major provisions granted legal status to undocumented immigrants who had continuously lived in the

17 "Illegal Alien Resident Population." Department of Homeland Security. https://www.dhs.gov/xlibrary/assets/statistics/illegal.pdf.

${ }^{18} \mathrm{Id}$. 
United States since 1982, legalized certain agricultural workers, enacted sanctions for employers who knowingly hired undocumented workers, and increased enforcement at U.S. borders. ${ }^{19}$ Following the implementation of the IRCA, the irony is that the greatest number of apprehensions by the border patrol for illegal crossing happened in $1986 .^{20}$

\section{Conclusion}

Contrary to popular belief among most Americans, there had been strides taken towards developing stricter immigration laws and policies prior to Bill Clinton's presidency. However, it can be argued that these immigration measures were ineffective in stopping the mass flow of illegal immigrants from Mexico. Even though most Americans pushed for stronger immigration policies, President George H. W. Bush signed into law the Immigration Act of 1990 (IMMACT) that actually increased legal admissions. Californians reacted to the burdens of illegal immigration in their state by passing Proposition $187 .{ }^{21}$ This proposition was promoted by then governor Pete Wilson in a bitter political clash that was a precursor to today's political climate on the issue of immigration. Prop 187 created a state-run screening system that prevented illegal immigrants from using non-emergency health care, public education, and other services in California. ${ }^{22}$ However, one month after Proposition 187 passed, a judicial order ruled it to be unconstitutional and prevented the implementation of the newly voter-passed

\footnotetext{
${ }^{19}$ H.R. 3810, $99^{\text {th }}$ Congress. (October $\left.9^{\text {th }}, 1986\right)$ (enacted).

${ }^{20}$ Office of Policy and Planning, and Department of Homeland Security. Estimates of the Unauthorized Immigrant Population Residing in the United States. https://www.dhs.gov/xlibrary/assets/statistics/publications/Ill_Report_1211.pdf.

21 Prop 187. 1994. (Passed).

${ }^{22} I d$.
} 
proposition, declaring that voters could not pass a law regarding federal jurisdiction of immigration. ${ }^{23}$

Operation Gate Keeper, which became law in 1994, was major immigration legislation passed early in Clinton's first term and would be one of the strictest immigration policies passed during the Clinton presidency. However, the law was one step in the right direction towards a stronger national security policy, but was two steps back in the implementation of the law. The goal of Operation Gatekeeper was to severely limit illegal immigrants from entering the United States; however, the number of illegal immigrants instead rose from 5.7 million in 1995 to 8.6 million in $2000 .{ }^{24}$ This increase of illegal immigrants illustrates the failed implementation and lack of resolve to accomplish the goals of Operation Gate Keeper. If the operation did not lower illegal immigration, did Clinton and his administration view it as a failure? The upcoming presidential election of 1996 encouraged Clinton to try and gain the support of California voters, and those states bordering Mexico. This means that motives behind Operation Gatekeeper were partially politically driven, rather than because of the consequences of illegal immigration.

While there has been a lot of research on Mexican immigration pre- and post9/11, which will be examined in Chapter 2, and most of the immigration research looks at the passage of immigrants into the United States and the effects of the legislation that was passed. There has been little research that analyzes the failure of both Clinton and Bush to properly secure the Mexican-American border. It can be argued that failed laws and

\footnotetext{
${ }^{23}$ McDonnell, Patrick J. “Prop. 187 Found Unconstitutional by Federal Judge.” Los Angeles Times, November 15, 1997.

${ }^{24}$ U.S. Immigration and Naturalization Service. Office of Policy and Planning. Estimates of the Unauthorized Immigrant Population Residing in the United States. Accessed February 20, 2019. https://www.dhs.gov/xlibrary/assets/statistics/publications/Ill_Report_1211.pdf.
} 
policies that affected Mexico extended to other lax immigration laws like the Visa Waiver Program and how their failures attributed to the eventual terrorists attacks on $9 / 11$

Chapter 3 begins by looking at the start of Clinton's second term in office, including the Visa Waiver Program, which is the immigration program that allowed the 9/11 terrorists to legally enter the United States. It is important to note that legislation passed by Congress and implemented during Clinton's first term will be of importance, especially Operation Gate Keeper, and how the policies affected both legal and illegal immigration during his second term. Rhetoric during the implementation of Operation Gatekeeper will be analyzed since it is important to the immigration debate prior to 2001 . The political environment is a key factor that will be looked at, specifically during the 1996 reelection of President Clinton. This chapter will look at how this election played an important role in the decisions made by the Clinton administration. This chapter concludes with an analysis of the 2000 presidential campaign of George W. Bush, and how he appealed to Mexican-American voters, as well as immigration reform policies during the first nine months of 2001, prior to September $11^{\text {th }}$.

Chapter 4 will start by examining the three major pieces of legislation that were passed by Congress and signed by President Bush following the 9/11 terrorist attacks and how they drastically impacted immigration policies related to Mexico: the Anti-Terrorism Act of 2001, the Homeland Security Act of 2002, and the Patriot Act. This chapter concludes by analyzing how 9/11 transformed the Mexican-American border and how these three pieces of legislation further resulted in policies that affected legal and illegal immigration. 
The concluding chapter provides research that argues it should not have taken a catastrophic event like the terrorist attacks in New York City and two additional 9/11 attacks on American soil that caused the death of more than 3,000 innocent lives to realize the urgent need for stronger national security in the homeland. Weak immigration laws and implementation policies since the early 1990s and throughout Bush's eight years in office did not discourage millions of illegal immigrants from Mexico and Central America. Therefore, the United States federal government and several southern border states have taken on the social, economic, and criminal burden of illegal immigration.

This chapter will also reason that due to the political environment of the time, Clinton and Bush were influenced to be tough on illegal immigration. For Clinton, Prop. 187 was critical in his stance on illegal immigration as he was seeking reelection in 1996. For Bush, the domestic terror on 9/11 significantly influenced his strong national security stance. This chapter will also argue that illegal immigration is a national security issue. Finally, the conclusion seeks to answer the following questions: Why didn't the United States Congress and President Clinton pass laws and implement strong policies and/or executive orders dealing with the politically divisive problem of illegal immigration? And, how did President Bush fail to take advantage of the 9/11 window of opportunity to fully strengthen United States immigration laws that would have permanently strengthened America's southern border with Mexico? 


\section{CHAPTER 2}

"Great harm has been done to us. We have suffered great loss. And in our grief and anger we have found our mission and our moment. Freedom and fear are at war. The advance of human freedom - the great achievement of our time, and the great hope of every time - now depends on us. Our nation — this generation - will lift a dark threat of violence from our people and our future. We will rally the world to this cause by our efforts, by our courage. We will not tire, we will not falter, and we will not fail."

- George W. Bush, Address to the Joint Session of the $107^{\text {th }}$ Congress

When President George W. Bush declared a "War on Terror" on September 20, 2001 before the $107^{\text {th }}$ Session of Congress, political journalists and news media outlets immediately turned their attention to the politics of war. Journalists and authors began transcribing articles and novels concerning how the 9/11 terrorist attacks had transformed the immigration debate in America. As the country was mourning the nearly 3,000 killed, the government was enacting measures to strengthen border security to ensure that future terrorists could not cross United States borders. The majority of what was written explained the subsequent national and worldwide effect of the terrorist attacks, and how it was expected that new legislation would greatly improve national security. There also was a lot written about the failed national security policies that allowed the $9 / 11$ attacks to happen, as well as a continuing commentary on how the United States had initiated stricter national security policies after $9 / 11$. However, there has been little research that examined the increasing illegal immigration numbers from Mexico, which would have concluded that immigration policies enacted after 9/11 did little to stop illegal migration and were just as much a failure as those previously enacted. With all that was written, there is also scant analysis regarding why President Clinton and President Bush failed to tighten illegal immigrant crossings at the U.S.-Mexican border before or even after the September 11, 2001 terrorist attacks. This chapter analyzes the current research on 
Mexican immigration and will also look at writings concerning why the United States has the territorial jurisdiction and obligation to control its borders.

The Border Patrol in the 1990s

The United States Border Patrol, which was apart of the Immigration and Naturalization Service (INS) prior to 9/11, and then part of the U.S. Customs and Border Protection (CBP) in the United States Department of Homeland Security (DHS) following 9/11, is the federal law enforcement agency whose responsibility is to detect and prevent illegal aliens, terrorists and terrorist weapons from entering the United States, and prevent illegal trafficking of people and contraband. The Border Patrol is also in charge of immigration along the Mexico-United States border. Prior to the 9/11 terrorist attacks, the U.S. Border Patrol was solely focused on illegal immigration and drug control rather than having to stop terrorists.

In Border Games: Policing the U.S.-Mexico Divide, Peter Andreas agrees that after $9 / 11$, "these already overstretched agencies were now expected to reinvent themselves to play a frontline role against terrorism." ${ }^{, 25}$ Prior to the attacks, Border Patrol was strictly focused on finding drugs being smuggled across the border, not necessarily looking for possible terrorists.

Chapter 3 will evaluate how effectively the southern border was patrolled at the start and during President Clinton's second term. Even though there was an increased focus on drug smuggling, most Americans had a widespread fear of illegal immigrants

\footnotetext{
${ }^{25}$ Andreas, Peter. Border Games: Policing the U.S.-Mexico Divide. Ithaca, NY: Cornell University Press, 2009.
} 
pouring into the United States. Professor Andreas explains how many politicians, specifically then-Governor of California Pete Wilson, played upon these sentiments:

"In a brilliant political move, Governor Pete Wilson of California revived his floundering 1994 electoral campaign by blaming the state's woes on the federal government's failure to control the border. His most effective tool for communication of this message was a television advertisement based on video footage of illegal immigrants dashing across the border from Mexico into the southbound traffic at the San Ysidro port of entry. Against the background of this chaotic scene the narrator's voice said: 'They keep coming. Two million illegal immigrants in California. The federal government won't stop them at the border, yet requires us to pay billions to take care of them. Governor Wilson sent the National Guard to help the Border Patrol. But that's not all... I am suing to force the federal government to control the border and I'm working to deny state services to illegal immigrants. Enough is Enough. ${ }^{, 26}$

During the 1990s, illegal immigration was stereotyped by the footage of illegals swarming the border like locusts, almost animalistic and to be feared. Even though the nation was beginning to reach economic prosperity, Clinton defended his border immigration reform policies, "We can't afford to lose control of our own borders at a time when we are not adequately providing for the jobs, health care, and the education of our own people. ${ }^{27}$ While some political historians believe Clinton was strong -- almost too strong in some areas -- on immigration after his reelection and to the end of his presidency, immigration was a low priority issue for Clinton at the beginning of his first term before it eventually became one of his highest priorities. In 1993, Clinton held a news conference where he proclaimed that there must be a strong message against illegal immigration and that the United States must make it tougher for them to enter. This set the tone for his future immigration policies and recommendations to Congress for stronger immigration reforms. During Clinton's presidency, the Immigration and

\footnotetext{
${ }^{26}$ Andreas, supra note 25

${ }^{27}$ ABC News, This Week with David Brinkley, 20 June 1993
} 
Naturalization Service's (INS) budget nearly tripled from $\$ 1.5$ billion to $\$ 4.2$ billion, as more than $\$ 3$ billion was spent on border security between 1994 and $1998 .^{28}$

Professor Andreas makes solid points when he cites that the number of Border Patrol agents more than doubled, the budget nearly tripled, the number of arrests more than doubled, and new fencing went up along the border. However, even with all of these new immigration policies during Clinton's term, the number of illegal immigrants in the United States still rose from 5.7 million in 1995 to 8.6 million in $2000{ }^{29}$

While Andreas argues that it became more difficult for immigrants, he does not fully analyze why they were still able to cross the border illegally at record numbers. $\mathrm{He}$ does suggest that because of the stronger laws, the "smuggling of migrants across the U.S.-Mexico border has become a more organized business, which has served to justify still tougher laws and tougher enforcement. ${ }^{, 30}$ But still Andreas does not come to any concrete conclusions why Clinton's new but flawed regulations and enforcement policies did not better prevent illegal immigration.

Like Andreas's work, most authors' pre-September 11 have argued that there was a concentrated focus on illegal immigration. Andreas even points out that although there was a rise in illegal immigration, there was still an increase in security on the border. Andreas does briefly discuss how 9/11 terrorist attacks affected the U.S.- Mexico border, even though he argues that the more "important" border control failure was the Visa Waiver program and those "issued to the hijackers by the consulate offices overseas."31 Like most authors who look at policies before and after 9/11, their claims that border

\footnotetext{
${ }^{28}$ Andreas, supra note 25

29 "Illegal Alien Resident Population." Department of Homeland Security. https://www.dhs.gov/xlibrary/assets/statistics/illegal.pdf. (Accessed February 19th, 2019)

${ }^{30}$ Andreas, supra note 25, at 97

${ }^{31} I d$. at 153
} 
security was tightened have become their strongest argument. However, if Clinton and Bush had supposedly strong immigration policies, why weren't they strong enough to prevent the increases in illegal immigrants from coming into the United States? Andreas argues that immigration policies did strengthen after $9 / 11$, and that the numbers of illegal immigration and crimes committed by these immigrants had previously increased over the years. If the policies were supposed to strengthen, then there must be another answer to the increases in illegal immigration.

Following the attacks, the borders were heavily tightened. Andreas gives the example that prior to 9/11 in Laredo, Texas, to enter the border took 5-10 minutes. Immediately following the attacks, it increased up to five hours. During this time, trade with Mexico was a major role in Mexican economics. Prior to these terrorist attacks, trade with Mexico had trumped security. However, following the attacks, security trumped trade. This is evident in the funding of the border patrol and the hiring of border patrol agents. By 2009, the border patrol was more than double the size than it was in $2001 .^{32}$

Andreas's point was that there was a focus during Clinton's term on immigration and strengthening the border. But following 9/11, there was a major crackdown on the border that slowed down the process of coming into the United States. There is a disconnect between these two times, because Clinton's legislation is viewed as being "too strict" by most authors, including Andreas, yet still allowed millions of illegal immigrants to enter. And now with regards to following 9/11, the borders became even more strict, however, there is a lack of research to argue it was not effectively done because illegal

\footnotetext{
${ }^{32}$ United States. Department of Homeland Security. Customs and Border Protection. U.S. Border Patrol Fiscal Year Staffing Statistics (FY 1992 - FY 2018). U.S. Customs and Border Protection.
} 
immigrants were still able to enter the United States at record highs, even following the 9/11 terrorist attacks.

Rhetoric of Immigrants and the Militarization of the Border

Much of the research following 9/11 has been focused on the rhetoric of immigrants, and how both legal and illegal immigrants have become connected to terrorism. Chapter 4 will argue that it is reasonable for illegal immigrants who are illegally entering the United States to be considered criminals because, in the first place, they are knowingly breaking U.S. law when they cross the border. For the families who want to migrate into the United States legally, there has been a legal process for them to enter legally. There has been a lot of research that looks at how immigrants are viewed post-9/11, and how this allowed for the militarization of the border. The rhetoric toward immigrants has been caused by fear of another terrorist attack, which reflects the failed immigration policies immediately following $9 / 11$.

The language and rhetoric towards immigrants also changed following the 9/11 attacks, mostly due to the fear of terrorism. The most obvious change was by President Bush immediately following September 11. Even though the terrorists did not come from Mexico, Bush encouraged citizens to "resist suspicion or distrust of the foreign newcomer based purely on his or her foreignness.."33 When Bush correlated fear with immigrants, this allowed the United States to militarize the border. Because fear is correlated with immigration, crime control becomes a central theme. In The Borders of Punishment: Migration, Citizenship, and Social Exclusion, the authors write, "In the

\footnotetext{
${ }^{33}$ Beasley, Vanessa B. Who Belongs in America? Presidents, Rhetoric, and Immigration. College Station, TX: Texas A\&M University Press, 2006.
} 
United States, Cisneros argues that visual images of immigrants appear as 'pollutants' in news media, collecting like piles of dangerous 'toxic waste' rolling towards the frightened US citizen. ${ }^{34}$ With a nationalist approach, a closed border is the solution to fear. With a fear of terrorists, the only solution is stronger prevention measures, like strengthening the borders while increasing the funds towards boarder security. Prior to 9/11, immigrants were not all feared as potential terrorists. Because of the recent terrorist attacks, there was a shift to the political and social immigrant paradigm. This is similar to the heightened security in airports following $9 / 11$. It is obvious that not all passengers are terrorists, but the heightened security is a measure to prevent terrorists from being able to easily board a plane. Similarly, not all immigrants entering the country are terrorists, but heightened security prevents those terrorists from easily entering.

When there is a domestic terror attack, not only does fear create a change to policy by the federal government, but citizens feel the necessity to take matters into their own hands. For the United States, citizens became national watchdogs. In Roxanne Lynn Doty's book The Law Into Their Own Hands: Immigration and the Politics of

Exceptionalism, she discussed the civilian led efforts that involved armed civilians on the U.S.-Mexico border surveying for illegal immigrants attempting to cross into the United States. Due to the resources by the government mostly on the California-Mexico border, immigrants shifted their approach to the Arizona-Mexico border, where the Minuteman Project held its front. The Minuteman Project was a volunteer-led organization where civilians became watchdogs along the Mexico border. The terrorist attacks on 9/11

\footnotetext{
${ }^{34}$ Aas, Katja Franko., and Mary Bosworth. The Borders of Punishment: Migration, Citizenship, and Social Exclusion. Oxford: Oxford University Press, 2013.
} 
created this window of opportunity to strengthen the borders, as these independent groups, like the Minutemen Project, used the terrorist attacks as a catalyst:

"When such societal groups perceive a threat to their security, a sense of emergency is generated and with it a willingness to take extraordinary emergency measures. The forms that "emergency measures" take can, of course, vary tremendously depending on the situation. Groups can take the law into their own hands in a variety of ways. They can offer their assistance to legal authorities. They can be violent or nonviolent. They can engage in symbolic practices in efforts to prompt the state to take action. Societal security highlights the fact that pronouncements of security concerns are not solely the purview of state actors.",35

Although Clinton's immigration policies were aimed at strengthening the border, if they were successfully implemented, there would not be a need for citizens to take action into their own hands. Doty looks at why citizens believed it was in their best interest to stand guard on the borders and help the border agents with their jobs. The immigration movement was present before $9 / 11$, however the terrorist attacks strengthened the link between the immigration movement and national security. ${ }^{36}$

One of the immigration movement organizations that Doty looks at is the Federation for American Immigration Reform (FAIR). FAIR's mission is “to improve border security, to stop illegal immigration, and promote immigration levels consistent with the national interest - more traditional rates of about 300,000 per year." ${ }^{37}$ This

\footnotetext{
${ }^{35}$ Doty, Roxanne Lynn. The Law into Their Own Hands: Immigration and the Politics of Exceptionalism. Tucson, AZ: University of Arizona Press, 2009, 13.

${ }^{36} \mathrm{Id}$.

${ }^{37} I d$.
} 
organization was created long before 9/11, in 1979 by environmentalist John Tenton. In 1999, during President Clinton's second term, FAIR went after Michigan Senator Spencer Abraham because of his pro-immigrant stance. The organization ran an ad with a picture that included the senator and Osama Bin Laden, titled "Why is a U.S. Senator Trying to Make it Easy for Osama bin Laden to Export Terrorism to the U.S.?” Doty argues that it is fear that creates the need for stronger borders. She argues that the events on September $11^{\text {th }}, 2001$ did "breathe new life" into the anti-immigration movement. It was U.S. Representative Duncan Hunter of California who proclaimed, "Prior to September 11, 2001, illegal immigration was considered a regional issue without national implications. We quickly learned on that day, however, that this is a national issue, affecting each and every American, not just those living in border communities like San Diego county."

When the media is highlighting anti-immigration groups and publicizing the fear of another terrorist attack, politicians feel the inclination to strengthen the border and improve national security policies. Although there was some legislation passed, the Mexican border was clearly never effectively secured in the years immediately following September $11^{\text {th }}$, illustrating failed national security policies. The reason organizations are creating this fear is because there was still a rise in illegal immigration immediately following these terrorist attacks, illustrating the need for a stronger national security policy. This fear has allowed the militarization of the border through the mission of "homeland security".

Militarization of the border is what the authors of The Borders of Punishment focused on throughout their book. "The border is policed not only by state-sanctioned 
personnel but also by private citizens. This combination of patriotism, vigilantism, and racism amplifies security concerns and suppresses the humanity of those crossing the border." ${ }^{38}$ Many of the writings on immigration make militarization seem evil and argue that the United States should not do so. But at what point does the United States strengthen our borders? When terrorists do enter the United States, at what point does the United States government have the right to protect its people by putting armed guards at the border? From 2001-2005, persecution on immigration law violations doubled, surpassing drug law violations as the most enforced federal law. The United States should have the power to enforce its laws, and it is not wrong to focus on border security following one of the biggest national terrorist attacks in the last century.

\section{The Sovereignty Debate - Territorial Jurisdiction}

The majority of the work done on immigration questions why there is an immigration debate, along with the reasons why countries protect its borders. Sovereignty is one reason why countries have the power and right to militarize at the border. Sovereignty is defined as the "authority of a state to govern itself." Sovereignty is the reason there is an immigration debate, as it allows the United States to "self-preserve." David Miller in

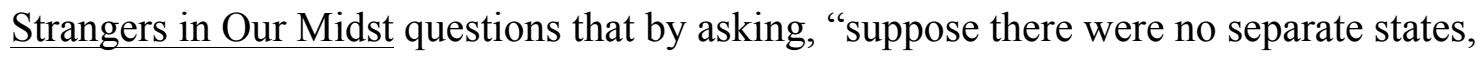
but simply administrative districts accountable to a world government of some sort. There would then be no immigration in the sense in which we understand it." ${ }^{39}$ But does this also mean that the United States could have closed borders and not let anyone in other than U.S. citizens? This would be a cynical view on immigration, yet still a valid

\footnotetext{
${ }^{38}$ Aas, Katja Franko., and Mary Bosworth, supra note 34

${ }^{39}$ Miller, David. Strangers in Our Midst: The Political Philosophy of Immigration. Cambridge, MA: Harvard University Press, 2018.
} 
approach because sovereignty allows militarization of the border. Understanding this concept of sovereignty is important when analyzing immigration policy, because it gives the power to the state actor to control who enters the country.

However, Miller argues that sovereignty is not a valid political argument. Miller believes that sovereignty does not give states ultimate power because it assumes that government power is the correct one without giving flexibility. Miller argues that the idea of territorial jurisdiction is a more "promising approach." ${ }^{, 40}$ This type of approach or theory is one that will be tied in the next chapters to the policy procedures set forth by Presidents Clinton and Bush. Miller first lays out his theory by looking at two parts of the claim: first, stating that it is important to establish what jurisdiction means and then how this correlates with border control. Miller defines jurisdiction as the means "possessing and exercising the right to make and enforce laws throughout that area of land, laws that apply to everyone who is physically present on the territory." ${ }^{41}$ The question Miller must then answer is, under what conditions can a state rightfully claim territorial jurisdiction?

Miller gives a three-part answer to this question. First, Miller reasons that a state "must maintain social order and protect the human rights of the inhabitants to a sufficiently high degree." ${ }^{, 2}$ Although the degree may depend, the state must be actively trying to uphold a degree of human rights, which may include having a military to protect its citizens, or a strong national security policy. In the United States, this would include having a legal system like the one created by the U.S. Constitution. The second condition that must be met is that the state must represent the inhabitants of the territory. This condition can be looked at from a few different angles, but the core meaning to it is that
${ }^{40} \mathrm{Id}$.
${ }^{41} I d$. at 58 .
${ }^{42} \mathrm{Id}$. at 59 . 
the people should regard the state as having legal authority over them. This does not include the dictatorships that force their leadership over the people, but instead the people accept the state for what it is. The way that condition is met in the United States is through a democratically elected government where there is representation of the people. The final condition is that "the people whom the state represents should themselves have the right to occupy the territory in question. ${ }^{, 43}$ This means that the state cannot forcibly remove the majority of the occupants and replace it with their own. It is important to note that these conditions are for modern politics, specifically since the $20^{\text {th }}$ century, so claims against the United States over the European colonization are not valid.

Now that the three conditions are laid out for territorial jurisdiction, it is understood that there are at least two rights that come with this jurisdiction. The first right is that the state has the right to control and use the resources that the land provides. The second is the right to control the movement of people and goods across its borders. Both these rights fall to the state as long as the three conditions are met. As mentioned, one of these conditions is to protect the human rights of its inhabitants. Miller argues that this also includes immigrants, which includes housing, education, and health care. However, Miller only uses the term immigrants, as if implying they are legal immigrants who entered the country legally. ${ }^{44}$ It should be argued that if an immigrant breaks the law to enter the country, almost like breaking the law to enter private property, then that immigrant forgoes these rights because they are breaking the laws from the state that has territorial jurisdiction.

\footnotetext{
${ }^{43}$ Miller, supra note 39.

${ }^{44} \mathrm{Id}$.
} 
Why is controlling the inflow of immigrants a crucial responsibility by the state? The condition regarding human rights can directly correlate with the influx of immigrants. For example, let's say a country has complete open borders. The influx of immigrants, thus an influx of population within the country, would prevent that state from being able to adequately maintain the human rights of all of its people. Because a state must be able to fulfill this condition, the state is thus able to control the amount of people that enters its territory. Miller makes the point that it "is not that a selfdetermining political community must close its borders, but that it must have the right to control its borders in order to preserve a meaningful range of policy choices without detriment to the human rights of those it choose to admit." ${ }^{, 45}$ This is a major claim because this means the United States has a right to control its borders, even if that meant having strict closed borders.

The main reason Miller argues the right for states to control its borders is because of population size. With the rise in state population, especially if the state is unable to hold a certain number of people, other factors become important. When a state is unable to support itself, there must be a limit where they can control its political and economic outcome. With a surplus of people, it becomes fiscally impossible to maintain the standard of human rights set out by the conditions of territorial jurisdiction. Miller uses global warming as an example, because the only way global warming would decrease is through the decrease use of carbon emissions ${ }^{46}$ However, with a surplus of immigrants into first-world countries, the use of carbon emissions would only drastically increase, thus making it impossible to solve this issue.

\footnotetext{
${ }^{45} I d$. at 62 .

${ }^{46} I d$. at 66.
} 
The rhetoric towards immigration is important to look at because it helps create the legislation that is passed towards immigrants. Although Miller makes the point that a state has conditions to meet, which means a state is allowed to control its borders, when the rhetoric towards immigrants is more violent and aggressive, it is more likely that migrant families looking for a better way of life are denied that opportunity. ${ }^{47}$

\section{Classification of Illegal Immigrants}

This classification of immigrants is exactly what Ngai in Impossible Subjects looks at. This classification is an important part of immigration policy because if immigrants are dehumanized as "aliens," then policies can be more consequential. Ngai looks at the historical origins of the term "illegal alien," which is from 1924 to $1965 .^{48}$ This term "alien" excludes the immigrants from society and prevents integration. Ngai argues that this classification is present before $9 / 11$, which indicates that $9 / 11$ was not a deciding factor in this classification. However, it is clear that $9 / 11$ brought the topic to a national level, because it forced people to believe that terrorists are currently migrating into the United States, even though there have been many cases where the terrorists were born in the U.S.

Ngai analyzes the "alien" classification of immigrants by looking at an extreme case of immigrant seclusion, the World War II internment of Japanese Americans. She argues how "alien citizenship" is "Asian Americans and Mexican Americans born in the United States with formal U.S. citizenship but who remained alien in the eyes of the

\footnotetext{
${ }^{47}$ Aas, Katja Franko, and Mary Bosworth, supra note 34, at 2.

${ }^{48}$ Ngai, Mae M. Impossible Subjects: Illegal Aliens and the Making of Modern America. Princeton, N.J.: Princeton University Press, 2014.
} 
nation." ${ }^{49}$ In the late 1950 s to early 1960s, Ngai argues that the fear of communism is what ignited the debate on border security, as "the New York Times estimated that in 1953, 1.5 million illegal immigrants streamed across the Mexican border, without so much as a How-do-you-do to an American immigration inspector." ${ }^{50}$ Ngai continues by explaining that it was not until 1965 that there were negotiations over immigration reform bills, as she coined the strict conservative immigration policy as the "Western Hemisphere immigration policy."

When classifying illegal immigrants as “aliens," it puts legal, integrated Mexican Americans in a tough spot. Because both groups of people, legal Mexican-Americans and illegal migrants, have a similar heritage, yet one group is viewed as criminals while the other is not. In Walls and Mirrors, Gutierrez analyzes the relationship between "illegal aliens," and legal born Mexicans. Illegal Aliens were categorized not only as possible terrorist, but were also seen to be uneducated and dangerous. "Already subject to the stigma of being Mexican in American society, many Mexican Americans feared that the mass immigration of impoverished, uneducated Mexican peasants would reinforce and inflame the negative stereotypes Americans already held about Mexicans." ${ }^{, 51}$ The terrorist attacks on September $11^{\text {th }}$ only heightened these fears by legal Mexican-Americans. Following the attacks, Mexican immigrants were viewed as "aliens" and tied to terrorism. The perception of illegal Mexican immigrants is similar to how the Japanese were viewed in America during WWII.

\footnotetext{
${ }^{49} \mathrm{Id}$.

${ }^{50} \mathrm{Id}$.

${ }^{51}$ Gutiérrez, David. Walls and Mirrors: Mexican Americans, Mexican Immigrants, and the Politics of Ethnicity. Berkeley: University of California Press, 2007.
} 


\section{Conclusion}

Regardless of the category immigrants are put in, citizens are still fearful of another domestic terror attack. In Coyotes: A Journey Across Borders with America's Mexican Migrants, Ted Conover reasons why the U.S.-Mexico border has U.S. citizens concerned and fearful:

This anxiety is not necessarily anti-immigrant; several of the 9/11 hijackers were also visa violators, and the fact that two of them received new student visas in the mail six months after perishing in the suicide attack on the Twin Towers does not bolster one's confidence in the Department of Homeland Security. Though a tiny fraction of the whole, migrants from nations besides Mexico use the southern border to sneak into the United States too. It seems only a matter of time until a terrorist is discovered to have come in via the border with Mexico. ${ }^{52}$

As previously discussed, if a country like the United States claims it has territorial jurisdiction, then they are allowed to patrol the border. However, if there has been this fear of illegal immigrants entering the country, why has the number of illegal immigrants continued to rise? As Douglas Massey answers in Beyond Smoke and Mirrors: Mexican Immigration in an Era of Economic Integration, it is due to the failed policies throughout the 1990s. The following chapters will specifically look at the policies that were enacted and systematically failed. However, Massey argues that when Operation Gatekeeper was passed, the majority of immigrants entered the United States through other ways. ${ }^{53}$ The

\footnotetext{
${ }^{52}$ Conover, Ted. Coyotes: A Journey across Borders with America's Illegal Migrants. New York: Vintage Books, 2006, 2.

${ }^{53}$ Massey, Douglas S., Jorge Durand, and Nolan J. Malone. Beyond Smoke and Mirrors: Mexican Immigration in an Era of Economic Integration. New York: Russell Sage Foundation, 2003.
} 
immigrants were funneled away from the way that was built in San Diego to entry points not in California. The reason why immigration seemed to be under control in the late 1990s was because immigrants simply snuck into the United States through other entry points.

With citizens believing the border was under control and with the unemployment reaching record lows by the late 1990s, the political debate on illegal immigration seemed to have disappeared. "On the contrary, by pushing migration away from urbanized areas and toward sparsely populated sectors, the Border Patrol had effectively channeled migrants towards portions of the border where they would be less likely to be cause, for in addition to being less inhabited, the new crossing points were also less patrolled." 54 Simply put, these new policies were only decreasing the amount of arrests because illegal immigrants were forced to enter the United States at places they were less likely to be caught at. Just because there were fewer arrests, does not mean these policies were working.

As Miller outlined the conditions that must be met, the one condition that almost all national security and immigration laws can be related to is the protection of human rights. One of these human rights is that the State must maintain the well being of their peoples' health. One reason why this thesis is focusing on the Mexico-U.S. border is because of the drug epidemic in the country. As Howard Buffet argues in Our 50-State Border Crisis: How the Mexican Border Fuels the Drug Epidemic Across America, "federal officials routinely estimate that 90 percent of the illegal drugs smuggled into our country are coming from or through Mexico, where the drug cartels have assumed unprecedented power through violence and corruption at every level of government and ${ }^{54}$ Id. at 131 
law enforcement. ${ }^{, 55}$ Buffet illustrates the drug problems he personally saw in Arizona. He outlined how he saw the immigration program first-hand from their farm in Arizona, which was about fifty miles from the border. He felt like he was in an "active conflict zone in the developing world" because of the armed smugglers he would see entering the country. "These experiences and investments of my time and resources have convinced me that border security is one of the most critical national security issues we face. ${ }^{56}$

Although Buffett's statements may reflect his personal held beliefs, there also exists a factual basis from his claims. Here are just a few facts Buffett wrote about that best illustrate the drug problem coming from Mexico. First, an American dies every eleven minutes from a drug overdose. ${ }^{57}$ Remember, about 90 percent of the heroin in the United States has come from Mexico. ${ }^{58}$ Second, the number of drug overdoses kills more Americans than motor vehicle accidents, and just in 2016 alone, exceeded the total number of U.S. causalities for the duration of the Vietnam War. ${ }^{59}$ It may seem astonishing, but if there were stricter border security measures, these drugs may not enter the United States, and there would be less of a threat to American citizens.

"We have to face reality: Our appetite for illegal drugs and our failure to secure the border have had terrible consequences for American citizens and those threats are in many ways intensifying. ${ }^{, 60}$ John Kelly, who was the former secretary of Homeland Security, addressed the U.S. Senate by proclaiming that while 3,000 Americans were

\footnotetext{
${ }^{55}$ Buffett, Howard G. Our 50 State Border Crisis: How the Mexican Border Fuels the Drug Epidemic across America. New York: Hachette Books, 2019.

${ }^{56} I d$.

${ }^{57}$ Hedegaard H, Miniño AM, Warner M. Drug overdose deaths in the United States, 1999-2017. National Center for Health Sciences Data Brief, no 329. Hyattsville, MD: National Center for Health Statistics. 2018.

${ }^{58} I d$.

${ }^{59} \mathrm{Id}$.

${ }^{60}$ Buffett, supra note 55
} 
killed by terrorism on $9 / 11$, more than half a million have died from illegal drugs. Although it is fair for citizens to be nervous of another terrorist attack, another concern about having loose border security is the drug traffickers that are killing at all time highs. Although this research is not solely focused on the drug cartel problem in the United States, it is a valid reason why the research focuses on the U.S.-Mexican border.

As previously mentioned, drug cartels were the sole purpose of border patrol prior to $9 / 11$, but when these terrorist attacks happened, the search for terrorists also was added to their to-do list. Buffet concludes his research by outlining his call to action, which is a reform of the border patrol. Buffet believes that it would be a mistake to militarize the border, but instead expand the border patrol to its own organization like the CIA. Buffett's main call to action is to work more with Mexico, since the majority of immigrants who cross into the United States are not criminals. Ultimately, the calls to actions are focused at the drug problems that the U.S. faces with Mexico, not necessarily just a wall.

It is clear that illegal immigration should be analyzed by focusing more on the conditions at the U.S.-Mexican border. With knowing that most illegal drugs come from Mexico, and the rising influx of illegal immigration since the early 1990s, the real question is why didn't presidents Clinton and/or Bush implement stronger border security policies to eliminate the issues that are a result from a weak border with Mexico? It has been demonstrated why the United States has a right to patrol its borders, yet it is evident that failed policies have allowed illegal immigration to grow. In order to best understand why illegal immigration still increased after President Clinton's proposed legislation was passed by Congress, and why it still increased following the terrorist attacks on 
September 11, it is imperative to comprehensively look at the failed legislation and what went wrong. 


\section{CHAPTER 3}

"All Americans, not only in the States most heavily affected but in every place in this country, are rightly disturbed by the large numbers of illegal aliens entering our country... We are a nation of immigrants. But we are also a nation of laws. It is wrong and ultimately self-defeating for a nation of immigrants to permit the kind of abuse of our immigration laws we have seen in recent years, and we must do more to stop it."

-President Bill Clinton, Address before a Joint Session of the Congress on the State of the Union, January 24, $1995^{61}$

When Bill Clinton was elected to a second term as president of the United States in 1996, immigration reform was already underway. It seemed that Clinton's "strong" immigration policies were among many that led him to a successful reelection campaign. Immigration policies were discussed in his State of the Union address in 1995: “... since 1992, we have increased our Border Patrol by over 35 percent; deployed underground sensors, infrared night scopes, and encrypted radios; built miles of new fences; and installed massive amounts of new lighting.." ${ }^{.2}$ During the 1990s, there was an equitable fear due to the significant rise in illegal immigration. According to the Immigration and Naturalization Service (INS), there was a rise from 3.5 million unauthorized aliens in 1990 to 5.8 million by $1996 .{ }^{63}$ INS estimated that about 41 percent, or 2.1 million, had overstayed their visas, while the other 3.7 million were assumed to enter illegally. ${ }^{64}$ The INS also estimated that Mexican undocumented immigrants accounted for 64 percent of

\footnotetext{
${ }^{61}$ President Bill Clinton, Address Before a Joint Session of the Congress on the States of the Union (Address to Congress, Washington, DC, January 24, 1995), C-Span, https://www.cspan.org/video/?54050-1/1994-state-union-address.

${ }^{62} I d$.

${ }^{63}$ U.S. Immigration and Naturalization Service. Office of Policy and Planning. Estimates of the Unauthorized Immigrant Population Residing in the United States. Department of Homeland Security. Accessed February 20, 2019. https://www.dhs.gov/xlibrary/assets/statistics/publications/Ill_Report 1211.pdf.
} 
all the illegal immigrants in $1996 .{ }^{65}$ There are only two ways an illegal immigrant can enter the country. First, they overstay their visa. This chapter will briefly look at the visa waiver program, and the statistical data of the number of illegal immigrants who overstay. The second way is through entering illegally across the border. Legislation that was passed tried to address both scenarios.

As such, this chapter looks at the legislation passed to limit illegal immigration. Operation Gatekeeper, which aimed to tighten the U.S.-Mexico border, was passed in the first term of President Clinton. Then, the Illegal Immigration Reform and Immigrant Responsibility Act of 1996 is considered, which was the most transformational immigration reform legislation passed during Clinton's presidency. Next, it is important to analyze the policies implemented aimed at strengthening the border, which was ultimately unsuccessful as the total number of illegal immigrants rose from 1990 to 2000 . Finally, considering the Bush presidential campaign in 2000 allows an assessment of obtaining the vote of legal Mexican immigrants through a strategy of rhetoric used during the campaign and in the early months of the Bush presidency. It will conclude by examining the pro-immigration legislation during the first nine months of 2000 . This analysis will be crucial in seeing the transformation of immigration politics pre and post $9 / 11$.

Visa Overstay and Statistical Analysis of Illegal Immigration of Mexican Immigrants In order for an immigrant to enter and stay in the United States longer than 90 days, they must have a U.S Visa. The only exception to this rule is through the Visa Waiver Program. The Visa Waiver Program began as a temporary program, known as the Visa ${ }^{65} I d$. 
Waiver Pilot Program, by the Immigration Reform and Control Act of 1986. The pilot program initially gave foreigners entry into the United States for 90 days or less if they were traveling for business or pleasure ${ }^{66}$ In order for a country to be a part of this program, they must have offered the same services to U.S. citizens while having an average non-immigrant refusal rate of 2 percent for the previous two years. ${ }^{67}$ There was a limit of eight countries that could participate in the pilot program before Congress began to expand the program through different legislation. ${ }^{68}$

Between 1986 and 1997, Congress enacted five significant pieces of legislations that made changes to the program, which included the Immigration Technical Corrections Act of 1988; the Immigration Act of 1990, which inserted further requirements for the program and removed the limit on the number of countries that could participate in the program; the Miscellaneous and Technical Immigration and Naturalization Amendments of 1991; the Immigration and Nationality Technical Corrections Act of 1994, which allowed countries who had higher than the previous 2 percent refusal rate, but less than 3.5 percent on a probationary basis; and the Illegal Immigrant Reform and Immigrant Responsibility Act of 1996, which created a probationary status for the countries that failed to meet the criteria, and had a refusal rate officially 3.5 percent instead of 2 percent. ${ }^{69}$

The pilot program was supposed to end in 1997, however the 105th Congress passed resolutions to continue the program. In 1998, Congress passed legislation to

\footnotetext{
${ }^{66}$ Department of Homeland Security. Office of Inspector General. The Visa Waiver Program. (2 November 2012). By Charles K. Edwards, Acting Inspector General. Accessed February 21, 2019. https://www.oig.dhs.gov/assets/Mgmt/2013/OIG 13-07 Nov12.pdf

${ }^{67} I d$. at 2

${ }^{68} I d$. at 2

${ }^{69}$ Siskin, Alison. Visa Waiver Program. Report no. RL32221. Pages 1- 28. December 11, 2015. https://fas.org/sgp/crs/homesec/RL32221.pdf. (accessed March 3, 2019)
} 
extend the program until 2000 and also made changes to the standard of what countries are selected to participate in the program. ${ }^{70}$ By 1999 , the program had grown from eight countries to include 29 countries. ${ }^{71}$ On October 30, 2000, the Visa Waiver Program was signed into law as a permanent program. ${ }^{72}$

Although the VWP is one way that immigrants could enter the United States, including all of the terrorists who committed crimes on $9 / 11$, Mexico is not an approved country for the program. ${ }^{73}$ Yet Mexican immigration was more than half of the total number of undocumented immigrants during the 1990s. ${ }^{74}$ The Visa Waiver program was an integral part of immigration reform in the late 1980s and early 1990s. However, this focus was ill advised since the majority of illegal immigrants were not because of this program. The Visa Waiver Program is important though because of the focus from congress during the 1990s.

The majority of illegal immigrants are from Mexico, which saw an increase from 1990 to 1999. Table 1 illustrates the statistical data from the Office of Policy and Planning in the Immigration and Naturalization Services. The INS uses the population numbers from the 2000 Census along with a series of analytical evidence.

\footnotetext{
${ }^{70} I d$. at 24

${ }^{71} I d$. at 24

${ }^{72} I d$. at 25

${ }^{73}$ Camarota, Steven. The Open Door: How Militant Islamic Terrorists Entered and Remained in the United States, 1993-2001. May 1, 2002. https://cis.org/Report/How-Militant-IslamicTerrorists-Entered-and-Remained-United-States. (accessed February 15, 2019)

${ }^{74}$ U.S. INS Report, supra note 63, at 13.
} 
Table 1: Estimated Illegal Immigrant Population, Top 15 Countries: 1990 and 2000

\begin{tabular}{|c|c|c|c|c|c|}
\hline \multirow[t]{2}{*}{ Country of Birth } & \multicolumn{2}{|c|}{$\begin{array}{c}\text { Estimated } \\
\text { Population in } \\
\text { January }\end{array}$} & \multicolumn{2}{|c|}{$\begin{array}{c}\text { Percent of } \\
\text { Total }\end{array}$} & \multirow{2}{*}{$\begin{array}{c}\text { Growth } \\
1990-2000\end{array}$} \\
\hline & 2000 & 1990 & 2000 & 1990 & \\
\hline All Countries............ & 7,000 & 3,500 & 100 & 100 & 3,500 \\
\hline Mexico.............. & 4,808 & 2,040 & 68.7 & 58.3 & 2,768 \\
\hline El Salvador................ & 189 & 298 & 2.7 & 8.5 & -109 \\
\hline Guatemala................. & 144 & 118 & 2.1 & 3.4 & 26 \\
\hline Columbia ............... & 141 & 51 & 2.0 & 1.4 & 91 \\
\hline Honduras................. & 138 & 42 & 2.0 & 1.2 & 96 \\
\hline China..................... & 115 & 70 & 1.6 & 2.0 & 45 \\
\hline Ecuador............... & 108 & 37 & 1.5 & 1.0 & 71 \\
\hline Dominican Republic... & 91 & 46 & 1.3 & 1.3 & 45 \\
\hline Philippines............. & 85 & 70 & 1.2 & 2.0 & 14 \\
\hline Brazil................... & 76 & 20 & 1.1 & 0.6 & 58 \\
\hline Haiti................... & 76 & 67 & 1.1 & 1.9 & 8 \\
\hline India.................... & 70 & 28 & 1.0 & 0.8 & 41 \\
\hline Peru..................... & 61 & 27 & 0.9 & 0.8 & 34 \\
\hline Korea................... & 55 & 24 & 0.8 & 0.7 & 31 \\
\hline Canada................... & 47 & 25 & 0.7 & 0.7 & 22 \\
\hline Other countries......... & 795 & 537 & 11.4 & 15.3 & 259 \\
\hline
\end{tabular}

Offic

e of Policy and Planning in the Immigration and Naturalization Services, 2000. (Numbers in thousands)

Table 1 illustrates the number of illegal immigrants from 1990 until 2000. The estimated illegal immigrant population from Mexico increased from about 2 million in 1990 to 4.8 million in January $2000 .^{75}$ Table 1 does not illustrate how many undocumented immigrants left the United States. However, the total number of illegal immigrants that arrived from 1990 until 1999 was about 4.7 million immigrants. ${ }^{76}$ Because there was a rise of 2.8 million, it can be estimated that about 1.9 million illegal immigrants were unaccounted for in the United States, which includes being removed by

\footnotetext{
${ }^{75}$ U.S. INS Report, supra note 63, at 13.

${ }^{76} \mathrm{Id}$.
} 
the INS, killed, emigrated, adjusted to lawful status in the United States, or departed briefly from the U.S. and return with immigrant visas.

Both the total number of illegal immigrants and the percent of illegal immigrants increased from Mexico increased during those 10 years. These estimates include all illegal immigration from Mexico during the 1990s. ${ }^{77}$ According to the INS, visa overstay in 1996 accounted for roughly 41 percent, or 2.1 million, of the total illegal immigrant population. ${ }^{78}$ Yet only 16 percent of the total number of illegal immigrants from Mexico are nonimmigrant overstays. ${ }^{79}$ Illegal immigration from Mexico rose from 58 percent to 68 percent from 1990 to 2000 . This means that the legislation that was passed was not successful in preventing Mexican illegal immigrants from entering. Although visa overstay is important, the focus should be preventing them from crossing the border.

Visa overstay is when an immigrant stays in the United States longer than the period of authorized stay, which may have been for several years. Illegal Immigrants who overstayed their visas was still a problem for President Clinton, because the legislation that he passed was focused on the California-Mexico border, and focused on those who were trying to enter illegally. Even though there are a high number of illegal immigrants entering through the border, 41 percent of all illegal immigrants overstayed their visas. There was not transformative legislation that was passed to lower this number.

In 1990, there were more than 2 million undocumented immigrants living in the United States. ${ }^{80}$ The Department of Homeland Security does not have comprehensive data illustrating how many illegal immigrants specifically from Mexico were deported

\footnotetext{
${ }^{77} \mathrm{Id}$.

78 "Illegal Alien Resident Population." Department of Homeland Security. https://www.dhs.gov/xlibrary/assets/statistics/illegal.pdf. (Accessed February 19th, 2019) ${ }^{79} I d$. ${ }^{80} \mathrm{Id}$.
} 
during the 1990s, only mass numbers of total immigrants deported. Table 2 illustrates the total number of deportations of illegal immigrants. ${ }^{81}$

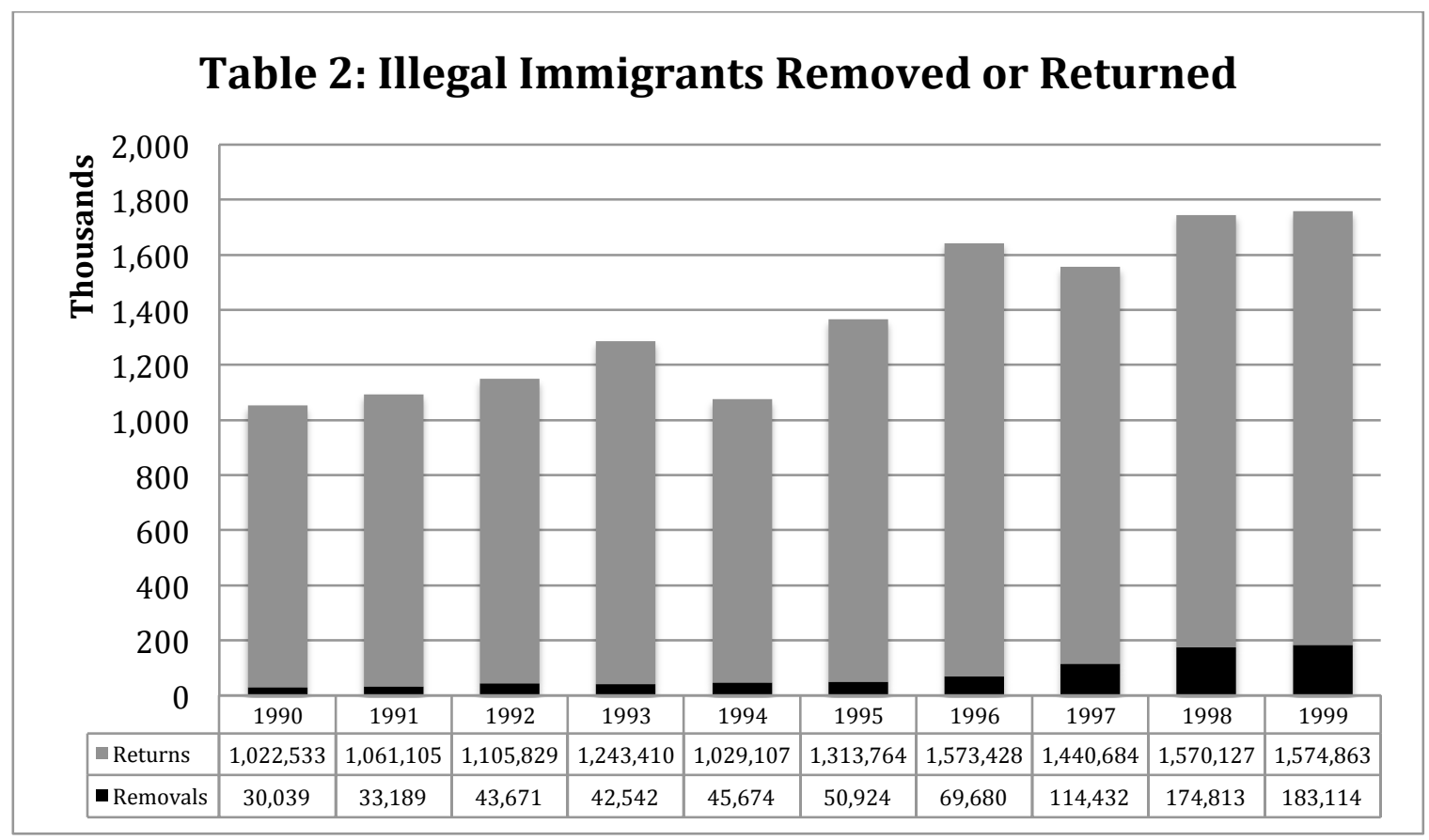

s. Office of Policy and Planning in the Immigration and Naturalization Services, 2000

Table 2 illustrates the two categories of deportations: returns and removals. Since 1927 , these are the two categories that are used by the Office of Immigration Statistics. ${ }^{82}$ "Removal" is referred to as what most assume deportation means: a lawful removal of an illegal immigrant who was living in the United States. ${ }^{83}$ The term "return" is more specific to immigration enforcement action, which usually means being apprehended at

\footnotetext{
${ }^{81} 2016$ Yearbook of Immigration Statistics. "Table 39. Aliens Removed Or Returned: Fiscal Years 1892 To 2016." Department of Homeland Security. November 30, 2017. https://www.dhs.gov/immigration-statistics/yearbook/2016/table39. (Accessed March 03, 2019). ${ }_{82} I d$.

83 "Definition of Terms" Department of Homeland Security. https://www.dhs.gov/immigrationstatistics/data-standards-and-definitions/definition-terms\#18 (Accessed February 25, 2019).
} 
the border. ${ }^{84}$ Instead of having legal proceedings like those individuals who are "removed", these immigrants are simply turned around and sent home. Individuals who are "removed" have a more significant punishment, as they can face jail time and/or are barred from coming back into the United States for a certain period of time. Those who are "returned" are not necessarily prevented from coming back.

When analyzing these two tables, it is shocking that the number of illegal immigrants removed or return increased from 1990 to 1999, yet the number of illegal immigrants residing in the United States from Mexico continued to increase. Although there was an increase of returns at a gradual increase every year, there was five times the number of removals in 1999 than in 1990. One hypothesis for why there was still an increase of illegal immigration in the United States was because immigrants would attempt to return to the United States more than once if they were simply "returned" at the border. Roughly 60 percent of illegal immigrants are from Mexico, and of these, more than 75 percent of them enter through the border. Knowing this, it is a strong indication that illegal immigrants were returning multiple times.

The second reason is due to visa overstay. Even if there were a lot of returns at the border, there were still ample amounts of immigrants overstaying their visas every year, and when the United States only deports 50,000 immigrants like in 1995, the number of illegal immigrants residing in the United States will drastically increase. ${ }^{85}$ Because of the lack of data regarding the number of illegal immigrants who overstayed visas and how many times on average an illegal immigrant would be returned before entering the U.S.,

\footnotetext{
${ }^{84} \mathrm{Id}$.

${ }^{85}$ DHS 2016 Yearbook, Table 39, supra note 81.
} 
it can only be assumed that it was drastically more than the number being deported. Both of these hypotheses are the result of failed policy and implementation of legislation.

\section{Operation Gatekeeper- The Death Trap}

Immigration Policy was at the forefront of political dialogue during Clinton's first term. Following the judicial overturn of Proposition 187, which was approved by voters in California, immigration reform was the next likely step. ${ }^{86}$ Clinton seized the opportunity in 1994 and launched “Operation Gatekeeper." In his address to Congress in 1995 when talking about illegal immigration, Clinton proclaimed:

"The jobs they hold might otherwise be held by citizens or legal immigrants. The public service they use impose burdens on our taxpayers. That's why our administration has moved aggressively to secure our borders more by hiring a record number of new border guards, by deporting twice as many criminal aliens as ever before, by cracking down on illegal hiring, by barring welfare benefits to illegal aliens. In the budget I will present to you, we will try to do more to speed the deportation of illegal aliens who are arrested for crimes, to better identify illegal aliens in the workplace as recommended by the commission headed by former Congresswoman Barbara Jordan. ${ }^{87}$

Operation Gatekeeper was enacted in order to militarize the border and limit the number of illegal immigrants from entering the United States. In Table 1, the number of

\footnotetext{
86 "General Election - Statement of Vote, November 8, 1994", California Secretary of State, statistical data, accessed March 3, 2019, https://www.sos.ca.gov/elections/priorelections/statewide-election-results/general-election-november-8-1994/statement-vote/\#ssov ${ }^{87}$ Clinton, Bill. Address to Congress. 1995.
} 
illegal immigrants in the United States decreased in 1996 and 1997, which is due to these policies in Operation Gatekeeper. ${ }^{88}$ However, it is evident that Operation Gatekeeper was only a temporary solution because in the years leading up to 2001, there was a drastic increase of illegal immigrants in the United States. ${ }^{89}$ And although the number of illegal immigrants decreased in 1996 and 1997, it was still more immigrants than in $1993 .^{90}$

The goal of Operation Gatekeeper was to deter illegal immigrants from entering the southern most border of California, where at the time the majority of immigrants were entering. The idea of Operation Gatekeeper was to make it more difficult for illegal immigrants to enter into the United States by building a wall in the most traveled paths, specifically the California-Mexico border. In addition to the building of a fence, there was a significant increase in the number of border agents and the funding for border security by the U.S. Government. In the early 1990s, over half a million apprehensions of illegal immigrants in the San Diego sector, which is the first fourteen miles from the Pacific Ocean inland, of the U.S.-Mexican border accounted for 45 percent of the national total. ${ }^{91}$ Clinton was soon seeking reelection, and illegal immigration paved the way to gain national support. He wanted to ensure that he received the votes of Californians who had recently voted for Prop 187 and wanted to secure the border in their state.

Operation Gatekeeper paved the way for the concept of "Gatekeeper Complex," which refers to allocating resources towards the deterrence of illegal immigration along traditional migrant routes, which ultimately increased the number of illegal immigrant

\footnotetext{
${ }^{88}$ U.S. INS Report, supra note 63, at 13.

${ }^{89} \mathrm{Id}$.

${ }^{90} \mathrm{Id}$.

${ }^{91}$ Madeline J. Hinkes, "Migrant Deaths Along the California-Mexico Border: An Anthropological Perspective," Journal of Forensic Sciences 53, no. 1 (January 2008): 16.
} 
deaths attempting to cross the border. ${ }^{92}$ Although it should not be the United States responsibility if a migrant dies trying to illegally cross the border, the number of illegal immigrants crossing the border into the United States still increased during Clinton's presidency. Operation Gatekeeper closed the traditional routes in the San Diego sector by constructing a fence and increasing funding along with the number of border patrol agents within that first 14 miles inland from the Pacific Ocean, while Operation Blockade did similarly in the El Paso sector of the border. ${ }^{93}$

The U.S. subsequently increased border security along the smaller towns near the border. This forced illegal immigrants to enter through the sparsely populated desert, which ultimately increased the likelihood of death without successfully deterring the majority of immigrants. ${ }^{94}$ Table 3 shows that although illegal immigration apprehensions decreased in the San Diego and El Paso sector, it increased in other sections of the border. $^{95}$

\footnotetext{
${ }^{92}$ Karl Eschbach et al., Deaths During Undocumented Migration: Trends and Policy Implications in the New Era of Homeland Security, Presentation Before the Twenty-Sixth Annual National Legal Conference on Immigration and Refugee Policy (Apr. 2003), in 26 IN DEFENSE OF THE ALIEN, at 37-52, 41, available at http://www.uh.edu/cir/Deathsduringmigr ation.pdf.

${ }^{93} \mathrm{Id}$.

${ }^{94} I d$. at 42

95 U.S. General Accounting Office, Report to Congressional Committees, GAO/GGD-99-44, Illegal Immigration: Status of Southwest Border Strategy Implementation 21 fig.8 (1999), http://www.gao.gov/archive/1999/gg99044.pdf [hereinafter Southwest Border Strategy Implementation]. Other Sectors include El Centro, Yuma, Tuscan, Mafa, Del Rio, Laredo, and McAllen.
} 


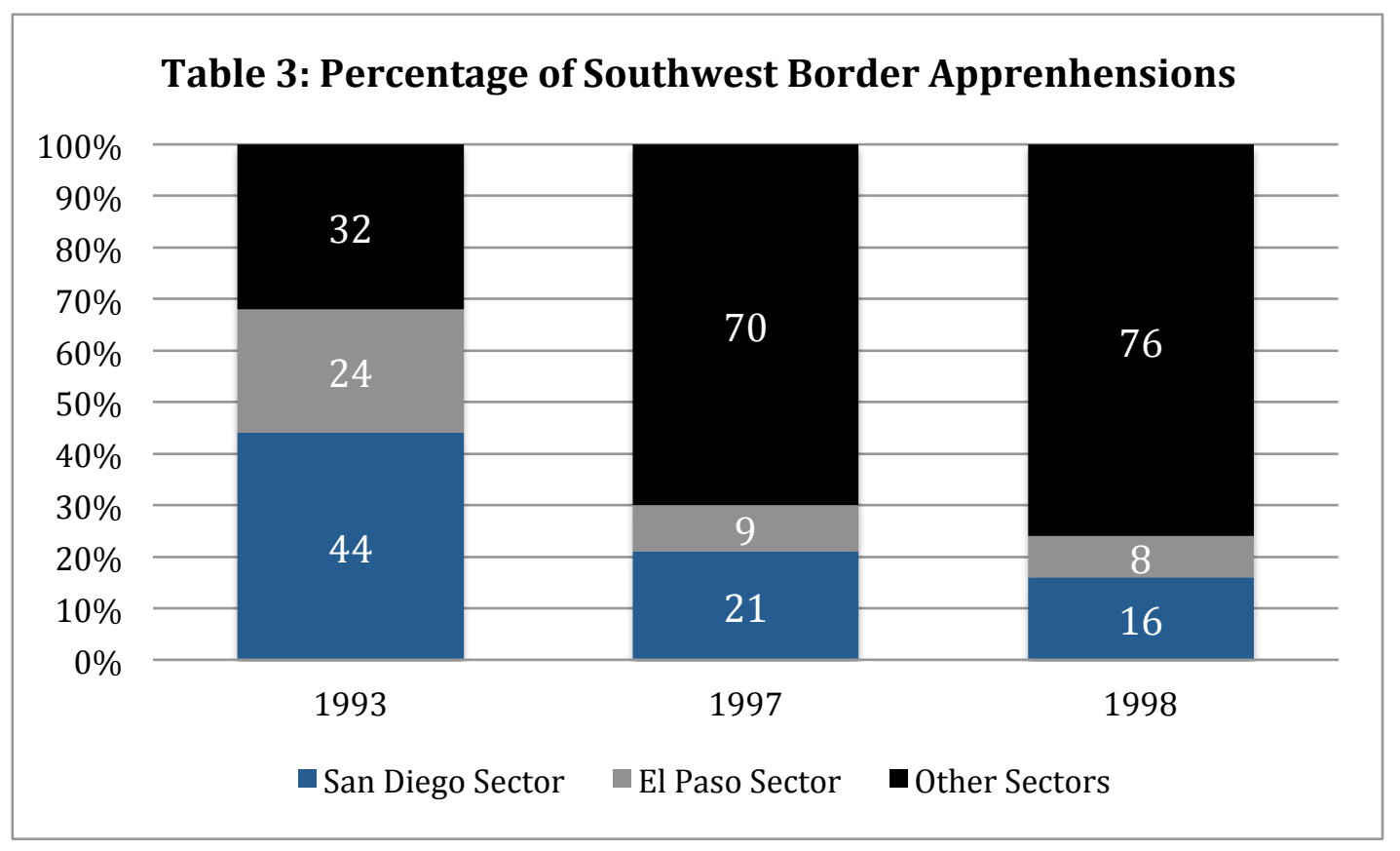

Source: United States General Accounting Office- Report to Congressional Committees. $^{96}$

Table 3 proves that Operation Gatekeeper was viewed as successful only because illegal immigration decreased in both the San Diego and El Paso sectors. Immigration and Naturalization Services believed that "intensified and targeted control would discourage many would-be migrants from even attempting the journey [across the Border] because of the additional physical difficulty, and the increased financial and psychological costs of the northbound journey. ${ }^{, 97}$ But the INS was wrong, because the number of illegal immigrants continued to increase. Ultimately Operation Gatekeeper did more to shift immigration patterns rather than lower illegal immigration into the United States.

Operation Gatekeeper shifted the immigration patterns to a more dangerous, less traveled route. Possibly the only more shocking statistic than the number of illegal

\footnotetext{
${ }^{96}$ Southwest Border Strategy Implementation

${ }^{97}$ Eschbach et al., supra note 92, at 40-41.
} 
immigrants who have successfully entered into the United States would be the number of illegal immigrants who have died trying to. Since the implementation of Operation Gatekeeper, the number of illegal immigrant deaths attempting to enter California has increased by 509 percent, as the death count grew from 23 to $140 .{ }^{98}$ From 1996 to 2000, the number of deaths in Arizona increased from 7 to 90, an increase of 1,186 percent, while in Texas the death count grew from 21 to 269 , an increase of 1,181 percent. ${ }^{99}$ The INS assumed that a more difficult path to the United States would prevent illegal immigration through deterrence, yet the growth in illegal immigrant deaths is concurrent with the number of illegal immigrants entering the United States.

Clinton portrayed Operation Gatekeeper as a success during his 1996 reelection campaign. Clinton knew he needed to win California during his reelection, so it is evident that is one factor that influenced his stance on illegal immigration. Clinton ended up winning the election by a good margin, due to the fact he won all the states bordering the Mexico border, except Texas. ${ }^{100}$ However, if it was not for Operation Gatekeeper and his strong stance on illegal immigration with Mexico, there is a chance Clinton would have lost key votes.

Although there was a decrease in apprehensions in the San Diego and El Paso sectors, the number of illegal immigrants continued to increase during this time. If the increasing number of illegal immigrants in the United States is not enough to deem Operation Gatekeeper as a failure, then the number of illegal immigrant deaths must correlate to the failed policies of the time. Why didn't Operation Gatekeeper build a complete wall? It is

\footnotetext{
${ }^{98}$ Eschbach, Karl, et al. "Death at the Border:' International Migration Review 33.2 (1999): 43054. Data from the Mexican Ministry of Foreign Relations

${ }^{99}$ Id.

100 "1982 Arkansas Elections". Arkansas Secretary of State. May 1983. Retrieved May 01, 2019.
} 
shown that the number of illegal immigrants drastically decreased in the sectors where the fences were built, but what would be the result if the wall/fence was completed along the entire border? Operation Gatekeeper was incomplete and inefficient, as lives were lost and the goal of decreasing illegal immigration was not achieved.

\section{Illegal Immigration Reform and Immigrant Responsibility Act of 1996}

Following Operation Gatekeeper in 1994, Clinton continued to ride the auspicious wave of immigration reform prior to his reelection campaign in 1996. Clinton realized that continued support for immigration reform would help to ensure that he would be elected to a second term in 1996 following the mass support of Operation Gatekeeper and other legislation that limited illegal immigration. On September $30^{\text {th }}, 1996$, Clinton signed into law the Illegal Immigrant Reform and Responsibility Act of 1996, which was one of the most transformative immigration laws of the decade. ${ }^{101}$ The new law represented the immigration initiatives following the Republican takeover of Congress after the 1994 midterm elections. Although Operation Gatekeeper was significant, the Illegal Immigration Reform and Immigrant Responsibility Act (IIRIRA) set the stage for significant U.S. illegal immigration control through stricter enforcement and increasing spending on the border.

IIRIRA first addresses the most publicly desirable subject of "Improvements to Border Control, Facilitation of Legal Entry, and Interior Enforcement." ${ }^{, 102}$ The most immediate impact of the bill was that it increased the number of border patrol agents by 5,000 over the next five years. It also increased the funding by $\$ 12$ million to the 14 -mile

${ }_{101}^{101}$ H.R. 2202, 104th Cong. (September 24, 1996) (enacted).

${ }^{102} I d$. 
fence, the same fence that Operation Gatekeeper created, in order to enhance its security. The security enhancements for the Immigration and Naturalization Service included helicopters, border patrol detection gear and vehicles. ${ }^{103}$ The IIRIRA also increased the civil and criminal penalties for illegal entry by fining every illegal immigrant $\$ 50$ to $\$ 250$, and the amount is doubled for repeat offenses.

Not only was there an increase of border protection, but there were several policy changes aimed at illegal immigrants residing in the United States. First, the law seeks to expand the staff that detects immigrants who have overstayed their visas. By 1997, there was a growth of 300 investigators, and by 1999 , there was an increase of another $600 .{ }^{104}$ Second, the IRA funded ways to expand nationwide surveillance through fingerprinting illegal immigrants arrested in the U.S. And lastly, the legislation took initial steps to federalize identification document standards. ${ }^{105}$

What this means is that it required the Social Security Administration to create counterfeit-resistant ID cards. ${ }^{106}$ The IIRIRA ordered the Attorney General to create a pilot program to increase employment eligibility verification, which included improvement to employment forms and a call-in system that allowed employers to check the legal status of job applicants. ${ }^{107}$ This trial program was only implemented in states that wanted to conform to these standards, and was mostly voluntary. It also required federal agencies to only accept birth certificates and state ID cards that had similar

\footnotetext{
${ }^{103}$ General Government Division. General Accounting Office. Illegal Immigration: Status of Southwest Border Strategy Implementation. Washington D.C., 1999.

${ }^{104}$ H.R. 2202, supra note 101.

${ }^{105}$ Espenshade, Thomas J., Jessica L. Baraka, and Gregory A. Huber. "Implications of the 1996 Welfare and Immigration Reform Acts for US Immigration." Population and Development Review 23, no. 4 (1997): 769-801. doi:10.2307/2137379.

${ }^{106} I d$.

${ }^{107}$ H.R. 2202, supra note 101.
} 
resistant measures. ${ }^{108}$ This allowed the security of immigrants who would use counterfeit ID cards to enter into the United States.

Many of the similar trends and issues that arose with Operation Gatekeeper were obstacles with the IIRIRA. The conclusion of this thesis will shed light on what could have been improved with the IIRIRA, and which aspects could be considered a failure. President Clinton had public support to eliminate the issues that came from the extreme increase of illegal immigration, yet only decided to partially fix the issue.

Why did President Clinton only build a wall 14 miles inland and then in El Paso instead of having extensive immigration deterrence along the entire border? It can be argued that there was no way to prove that President Clinton and H.R. 2202's deterrence solutions wouldn't work, since it was the first extensive immigration policy of the time. However, just because there was a decrease of detained immigrants in the San Diego sector, doesn't mean that the policy was a success. The fact remains that illegal immigrants were simply coming through less fortified entries.

Because the IIRIRA was the first of its kind, and the strictest of its time, the criminal aspect of detaining and deporting illegal immigrants created its own set of problems. Clinton described the IIRIRA as a bipartisan "landmark immigration reform legislation that cracks down on illegal immigration without punishing legal immigrants." 109 The "crack down" on illegal immigrants prior to this legislation was very limited in scope. The IIRIRA expanded illegal immigration enforcement by increasing the involvement of immigrants with the criminal justice system, which is important to know the different ways it did, especially prior to $9 / 11$ in order to see the transformation

\footnotetext{
${ }^{108} \mathrm{Id}$.

${ }^{109}$ President Clinton to Congress, supra note 61.
} 
of immigration policy after the terrorist attacks in 2001. This legislation set the way for laws that were passed after September $11^{\text {th }}$, like the Patriot Act and the Anti-Terrorism Act of 2001 .

There was at least four ways that the IIRIRA increased the involvement of illegal immigrants with the criminal justice system. First, the IIRIRA expanded the criminal grounds of deportation. The categories of "crimes of moral turpitude" and "aggravated felonies" were expanded to include some misdemeanors. The Immigration and Nationality Act effectively created to category of "aggravated felonies", which strips a legal immigrant of their citizenship since the degree of crime increased. ${ }^{110}$ The criminal classifications redefined the goals of the immigration system, as it seemed to criminalize immigrants who had a green card about to legalize. Although there should be a more effective legalization process, if an illegal immigrant commits a crime, there should be repercussions.

The second way that the IIRIRA increased immigrant involvement with the criminal justice system was through the nationwide fingerprinting of illegal immigrants that were detained. There were many illegal immigrants that were low-level in the drug economy, many low-income Mexican immigrants that were caught in the drug war. ${ }^{111}$ The Bureau of Justice Statistics did report that illegal immigrants were more likely than legal citizens "to have played a minor role in the drug conspiracy." 112 Since there was an expanded category of aggravated felony, it expanded the "criminal alien" classification.

\footnotetext{
${ }^{110}$ IIRIRA, supra note 101, at 105

${ }^{111}$ Scalia, John. 1996. Non-Citizens in the Federal Criminal Justice System, 1984-1994. Washington, DC: US Bureau of Justice Statistics.

${ }^{112} I d$.
} 
Third, the IIRIRA renamed the term "exclusion" to "removal," and created an expedited deportation process that limited immigrant's access to discretionary relief. It approved the "rescission of legal permanent residency status" affirming that "an order of removal issued by an immigration judge shall be sufficient to rescind the alien's status." 113 What this means is that it expedited the deportation process and allowed illegal immigrants apprehended at the border to be immediately removed, even asylum seekers without a convincing "credible fear of persecution." ${ }^{\text {"114 }}$ It allows INS officials to issue orders to illegal immigrants that prevented any relief from deportation.

What this meant was that it led to an increase in informal deportations that bypass the immigration courts and criminal prosecution. ${ }^{115}$ There are pros and cons to an expedited deportation process. Limited regulation and fewer procedural rights allowed many more illegal immigrants to be deported, which meant it was a lot cheaper to deport an illegal immigrant. However, this also meant that there was a higher chance that an illegal immigrant would attempt to reenter the United States because of the lack of harsh punishment. When an illegal immigrant is put through the court system, there are higher penalties for reentry, and more information entered into the system on that alien.

Finally, the IIRIRA created detention centers for illegal immigrants who have been detained. ${ }^{116}$ Instead of instantaneously deporting an illegal immigrant, there were legal steps to process them in addition to other procedures that were mandated. The IIRIRA created these detention centers to house illegal immigrants, which created more

\footnotetext{
${ }^{113}$ IIRIRA, supra note 101 , at 105

${ }^{114}$ Pistone, Michele R., and Schrag, Philip G. 1996. "The 1996 Immigration Act: Asylum and Expedited Removal: What the INS Should Do.” Interpreter Releases 73: 1565-79.

${ }^{115}$ Morris, Helen. 1997. "Zero Tolerance: The Increasing Criminalization of Immigration Law." Interpreter Releases 74(33): 1317-26.

${ }^{116}$ IIRIRA, supra note 101, at 105
} 
regulation and costly expenditures for illegal immigration. This created a new market for private corporations to build and manage detention centers, but cost the United States millions in 1996. The IIRIRA authorized $\$ 670$ million for state prison grants, with $\$ 170$ million made available for "alien incarceration". ${ }^{117}$ With a more efficient deportation process, it had been hoped that the passage of the IIRIRA would eliminate the time illegal immigrants were at deportation centers, thus saving the United States money.

The IIRIRA also allowed for the deportation of illegal immigrants that had been here for several decades even if they committed misdemeanor crimes 20 years ago. ${ }^{118}$ Although it is important to prevent illegal immigrants from staying in the United States, it can be argued that if an illegal immigrant has not committed any felony crime, should they immediately be deported without an opportunity to apply for residency? However, most Americans have little sympathy for illegal immigrants who commit felony crimes.

\section{President George W. Bush - The 2000 Presidential Election}

The election of President George W. Bush in 2000 seemed to mark a transition in United States immigration policy. In his presidential campaign during 1999, then-Texas Governor Bush claimed immigration reform was one of his national priorities, particularly since he was targeting the swing Latino votes in California, New Mexico, Arizona, Texas, Florida, and New York. "For those who want to wall off Mexico from Texas, I say you're dead wrong," Bush proclaimed in 1998. "For people who want to isolate Mexico from Texas through a psychological war of words, there could be nothing

\footnotetext{
${ }^{117}$ IIRIRA, supra note 100 , at 105

${ }^{118}$ Macías-Rojas, Patrisia. "Immigration and the War on Crime: Law and Order Politics and the Illegal Immigration Reform and Immigrant Responsibility Act of 1996." Journal on Migration and Human Security 6, no. 1 (2018): 1-25. doi:10.14240/jmhs.v6i1.110.
} 
worse. We share problems, we share a long border. But the best way to solve our common problems is to do so in the spirit of friendship and to treat each other decently." Even when California Governor Wilson endorsed Prop 187, Governor Bush was an advocate against it since it would have eliminated everything but emergency services to illegal immigrants. "Children already living in Texas should not be denied an education because of where they were born”, Bush said when visiting Mexico in 1995. In an interview with Francisco Barrio, who was then governor of Chihuahua state, which borders Texas, said that Governor Bush said, "Every child of an undocumented family in Texas will have access to health services and education, at least while I am governor". In a 1995 speech Governor Bush encouraged Congress to bail Mexico out of its economic troubles, "What is good for Mexico is good for the United States."

This rhetoric was prevalent during his 1999 presidential campaign. During his campaign, he emphasized his connections to Mexico, reminding Latino voters that he spoke Spanish and that his brother Jeb Bush, who was then Florida's Governor, was married to a Mexican American woman. He also reminded the voters of how he traveled as Texas governor to Mexico to improve border relations with Mexico. During one of the televised presidential debates, referring to Mexico's President-elect Vincent Fox, "He's a man I know from Mexico.” Bush was the first candidate to use a Spanish-language ad in a presidential primary. When candidate and then-President Clinton campaigned in California, he did not need to key on the Hispanic vote because statistics had shown that the majority of Latinos voted Democrat in recent elections. Republican candidate George Bush and his chief political strategist, Karl Rove, realized their top goal was to gain confidence with Latino voters. The Latino population represented the largest minority 
group in the United States. The Census Bureau population projections at the time expected dramatic decrease of white non-Hispanics, predicting a drop from 72 percent in 2000 to 64 percent by 2020 and 53 percent by $2050 .{ }^{119}$

In 1999, it was imperative for candidate Bush to dramatically increase his Mexican vote if he was to win the election. In the 1996 Presidential election, the Republican Party won only 21 percent of the Hispanic vote compared to the 72 percent who voted Democrat. This seemed surprising following President Clinton's strict immigration policies during his first term, but it illustrated the policy emphasis of the time. $^{120}$

In a dramatic increase from the previous Republican Party candidate, Bush nationally received 35 percent of the Hispanic vote, a 14-point swing from the 1996 election. These votes turned out to be crucial since the 2000 election was one of the most controversial ever. Florida ended up being the swing state and was necessary for Bush to win the presidency. On election night, Democrat Al Gore was declared the winner very early by national media stations. However, the next day Bush was declared the winner by a very close margin. Gore challenged the result due to inaccurate "butterfly ballots", which referred to the ballots that were not fully punched through, but the Supreme Court overturned Gore's challenge, which led to Bush winning Florida by 537 votes. ${ }^{121}$ Bush's campaign efforts toward Hispanic voters was definitely evident in the Florida campaign, since the non-Cuban Hispanic vote was split in Florida, 48 percent for Gore to 49 percent

\footnotetext{
${ }^{119}$ United States. U.S. Department of Commerce. U.S. Census Bureau. Overview of Race and Hispanic Origin: 2010. 2011.

${ }^{120}$ Louis DeSipio. 1996. Counting on the Latino Vote. Charlottesville, VA: University of Virginia Press.

${ }^{121}$ Elections, Division office. "November 7, 2000 General Election". results.elections.myflorida.com. Retrieved 2019-03-10.
} 
for Bush. ${ }^{122}$ The extra percent was the different between winning and losing the 2000 presidential election.

Since several Republicans in Congress also wanted to gain support of Hispanic voters in their elections throughout the country, they proposed the Agricultural Job Opportunity Benefits and Security Act of 1999. This legislation was introduced to help create an easier path for immigrants who were working and contributing to the United States economy. However, it was not passed because many members of Congress wanted to wait and see what immigration legislation that was going to be proposed by President Bush. It was clear that there was going to be new immigration reform in the early years of the Bush presidency.

2001 - Months prior to $9 / 11$

During the first nine months of the Bush presidency, there were significant changes in immigration policy. Bush was focused on making the citizenship process more efficient. There were three major legislation proposals during these first nine months. First, both chambers unanimously approved short-term extensions of section 245(i) of the Immigration and Nationality Act (INA). This provision allowed illegal immigrants to be eligible for green cards to become lawful, permanent residents without having to leave the country first. Second, there were bipartisan groups in both chambers that introduced versions of the Development, Relief, and Education for Alien Minors (DREAM) Act, which legalized the children who had entered the United States illegally and had

${ }^{122} I d$. 
graduated high school and attended college. ${ }^{123}$ Rep. Chris Cannon (R-UT) introduced this legislation in the House with 62 bipartisan cosponsors, and by Sen. Orrin Hatch (R-UT) in the Senate with 18 bipartisan cosponsors. Lastly, there was a pair of AgJOBS bills that were introduced with support from both sides of the aisle. The Republican-backed Agricultural Job Opportunity Benefits and Security (AgJOBS) Act of 2001 (S. 1161) was introduced by Sen. Larry Craig (R-ID) on July 10, 2001, and the Democratic H-2A Reform and Agricultural Worker Adjustment Act (HR 2736) was introduced during the 107th Congress by Rep. Howard Berman (D-CA) on August 2, 2001. ${ }^{124}$

The DREAM Act was a bipartisan effort that proves there was major immigration reform beginning to happen before the $9 / 11$ terrorist attacks. It is evident that Congress was focused on making the legalization process more efficient. However, there were no provisions in this proposal to focus on strengthening the border to prevent more illegal immigrants from entering the country.

The DREAM Act was a progressive immigration measure because it was aimed at legalizing children who achieved certain education milestones in the United States. These included attending and graduating from an institution of higher learning, being of a certain age to apply, being physically present in the U.S. for a certain number of years, having good moral character, and having not violated other immigration laws. ${ }^{125}$ These children were referred to as "DREAMers", which defined them as individuals who were

\footnotetext{
${ }^{123}$ HR 1918, Student Adjustment Act of 2001, 107th Cong., 1st sess. and S. 1291, Development, Relief, and Education for Alien Minors Act, 107th Cong., 2nd sess.

${ }^{124}$ Rosenblum, Marc R. US IMMIGRATION POLICY SINCE 9/11: Understanding the Stalemate over Comprehensive Immigration Reform. Report. Washington, D.C.: Migration Policy Institute, 2011.

${ }^{125}$ HR 1918, supra note 123
} 
brought into the country at a young age by parents who illegally immigrated and assimilated into American culture and educated in the United States.

The DREAM Act of 2001 failed to pass during the $107^{\text {th }}$ Congress, in part because of how most Americans reacted to the terrorist attacks of September 11, the predicted focus on terrorism, and new attitudes on illegal immigration in general.

President Bush strongly supported the DREAM Act and the other immigration reform efforts. During his campaign, he promised to speed up the immigration processing for immigrant families and employers. Bush argued that "immigration is not a problem to be solved; it is the sign of a successful nation." ${ }^{\prime 126}$ President Bush's passion in U.S.-Mexico relation was fueled by his relationship with the newly elected Mexican President, Vicente Fox. Fox became Mexico's first democratically elected leader, and had campaigned on similar messages of improving the U.S.-Mexico relationship. President Bush saw the improvement of U.S.-Mexico relations as his "signature foreign policy legacy", thus President Bush and Mexican President Fox met five times during the first nine months of $2001 .^{127}$ Some analysts described this fruition as an "absolutely historic transition from a hostile relationship to a cooperative relationship," and anticipated "more and more a kind of merged country on the border." 128

Conversations specifically to U.S.-Mexico relations were initiated by a binational task force that specifically dealt with the U.S.-Mexico relationship. Thomas F. McLarty, President Clinton's first chief of staff, chaired this task force along with Andres Rozental,

\footnotetext{
${ }^{126}$ George W. Bush, Renewing America's Purpose: The Policy Addresses of George W. Bush, 1999-2000 (Washington, DC: Republican National Committee. 2000), 195-97.

${ }^{127}$ Kenneth Walsh with Thomas Omestad, "Broader Border?” U.S. News \& World Report 131, August 20, 2001.

${ }^{128}$ Larry Birns of the Council on Hemispheric Affairs and M. Delal Baer at the Center for Strategic and International Studies, respectively, quoted in Walsh and Omestad, "Broader Border?"
} 
a former Mexican senior diplomat. This group met throughout 2000 and released the report Mexico-US Migration: A Shared Responsibility in February 2001 just before the two presidents met for the first time. ${ }^{129}$ The group even laid out a negotiation agenda, which became their starting point for conversation, in the memo "Memorandum to Presidents George W. Bush and Vicente Fox.”

Following the meeting between both presidents, the Secretary of State and the Attorney General of the United States and the Mexican ministers of foreign relations chaired a Working Group on Migration. "They tasked the group with developing a comprehensive bilateral migration deal encompassing legalization, border enforcement, and a new temporary visa program. In May, the countries announced a pair of border initiatives to discourage illegal migration through high-risk areas and to cooperate on humanitarian search-and-rescue operations. ${ }^{, 130}$ At this time, President Bush and his administration were discussing the possibility of a "grand bargain" that would legalize a mass majority of illegal immigrants in the Unites States. This "grand bargain", which was referred to as the "whole enchilada" in Castaneda's memo phrase, would include a bilateral guest work program, along with a larger Mexican presence at the border. ${ }^{131}$ On September $6^{\text {th }} 2001$, just five days before the terrorist attacks on $9 / 11$, Bush held a summit with Fox. At this summit, Fox challenged Bush to move the negotiations

\footnotetext{
${ }^{129}$ US-Mexico Migration Panel, Mexico-US Migration: A Shared Responsibility (Washington, DC: Carnegie Endowment for International Peace, 2001), www.carnegieendowment.org/pdf/files/M\%20exicoReport2001.pdf.

${ }^{130}$ Rosenblum, supra note 124

${ }^{131}$ Mexican Foreign Minister Jorge Castañeda used the phrase in June 2001 to link Mexican cooperation on guest workers and border security to legalization for unauthorized Mexicans in the United States. See Eric Schmitt, "Bush Aides Weigh Legalizing Status of Mexicans in U.S.," The New York Times, July 15, 2001.
} 
further, which led to both presidents formally committing to complete a deal by the end of the year. Bush said at this September $6^{\text {th }}$ summit:

And that is there are -- one of the things I have told the President is I am willing to consider ways for a guest worker to earn a green card status. And yet I fully recognize there are a lot of people who have stood in line, who have said, I'll abide by the laws of the United States. And we're trying to work through a formula that will not penalize the person who's chosen the legal route, and at the same time recognizes the contribution that the undocumented has made.... he's [President Fox] asked that we do it within the year. One thing he will find is that we will put 100 percent effort into it during the year. And I hope we can come up with a solution; I want to accommodate my friend.

This summit also produced agreement on a new public-private "Partnership for Prosperity", which was an agreement for the United States to promote investment in Mexico in order to reduce emigration pressures. The mission statement of this partnership is "To help address some of the root causes of migration, [President Fox and President Bush] agreed to form a public-private alliance to spur private sector growth throughout Mexico. This " initiative will harness the power of free markets to boost the social and economic well being of citizens particularly in regions where economic growth has lagged and fueled migration. The development of this alliance will be spearheaded by senior-level coordinators on both sides, and will draw on the best expertise among Mexican and U.S. economists, business people and civil society to develop a concrete plan of action to be presented to the Presidents not later than March 1, 2002." 
There was earnest progress in immigration reform, although it was not focused on prevention of immigrants since it was more aimed at the legalization of those illegal immigrants who have been working and living in the United States for many years. All of this seemed encouraging for the future until just a few days later. As the terrorist attacks of September 11, 2001 changed the United States, it also drastically changed what Americans were willing to accept in the way of new immigration policies.

\section{Conclusion}

Illegal immigration was a major social, economic, and political concern to Americans in the 1990s. President Clinton succeeded in getting reelected in 1996 because of his immigration reform policies. Although a federal appeals court had ruled Prop 187 unconstitutional, it had still been passed by California voters and was very much a hot topic. It's clear that Americans were tired of immigration problems from illegal migrants entering the United States. Operation Gatekeeper was President Clinton's solution to the problem, which built 14 miles of wall from the Pacific Ocean inland. However, as the numbers of illegal immigrant crossings and deportation increased during President Clinton's terms so did the total number of illegal immigrants residing in the United States. Operation Gatekeeper was seen by some as a success because of the limited number of immigrants who entered the California-Mexico border in the San Diego sector, meaning it was a success for 14 miles of the 1,954-mile southern border. However, the success of the 14-mile wall also funneled immigrants to a more dangerous terrain, which increased border crime and the number of illegal immigrants who died trying to cross the border. 
The Illegal Immigration Reform and Immigrant Responsibility Act of 1996 is seen as one of the most transformative immigration reform laws ever passed. These strict immigration guidelines increased federal government spending for security at the border. The number of illegal immigrants who entered the United States decreased in 1996 and 1997. However, the numbers shot back up in 1998 and 1999 as Congress relaxed immigration policies and unsuccessfully tried to create policies that would legalize illegal immigrants who were already living in the United States. Policies like the DREAM Act and Agricultural Job Opportunity Benefits and Security Act of 1999 only increased the number of illegal immigrants who believed the risk of deportation was worth their attempt to live in the United States.

Republican candidate Bush heavily campaigned for the Latino voters and was the first presidential candidate to use an ad in Spanish. This ad and his campaign to champion Hispanic causes led him to win 35 percent of the Hispanic vote, which was the most a Republican had received in decades. President Bush had a personal relationship with newly elected Mexican President Vicente Fox, and worked closely with him in the first nine months of 2001. There were major improvements in the early relationship between the United States and Mexico and some analysts have said it was the best relationship in recent history between the United States and Mexico. The September 6, 2001 summit had truly opened the door for future cooperation between the two nations.

But five days later, the landscape of the United States and the world was changed forever as the horror of the four terrorist attacks on September 11 shocked Americans in every corner of the country. The relationship with Mexico quickly changed when national security and border security became the top priority over immigration issues. All future 
talks between the United States and Mexico were put on hold. President Bush's new focus was to secure the southern border to ensure that terrorists could not cross into the United States.

The terrorist attacks just five days after the United States-Mexico summit completely transformed the immigration narrative. It was a missed opportunity. 


\section{CHAPTER 4}

On the morning of September 11, 2001, 19 militants connected to the radical Islamic terrorist group al-Qaeda killed nearly 3,000 people and injured over 6,000 others. In less than two hours in a series of four coordinated attacks, the U.S. faced at least $\$ 10$ billion in property and infrastructure damage, totaling to $\$ 3$ trillion in total costs. ${ }^{132}$ Americans were engulfed with anger and anguish, imposed with the realization that not all illegal immigrants were filled with peace, searching for prosperity. As the country began to mourn, politicians began to question how the largest domestic terrorist attack since Pearl Harbor transpired. As emergency disaster trainer and ACPO activist Kelly Sharp wrote describing the events of 9/11: "These attacks fundamentally changed the way people in the U.S. viewed our invincibility and brought terrorism to our front door. Today, although Osama bin Laden is dead, terrorism remains a threat to the United States and the possibility of another event like 9/11 cannot be discounted."

There were significant changes following the $9 / 11$ attacks. Just when analysts alleged a positive relationship with Mexico was cultivating, the terror attacks destroyed any such thought. How could the United States have allowed terrorists into the country? Politicians sought to answer this question. President Bush and his administration promptly focused on national security through the enactment of legislation intended to prevent terrorists from entering the country. It is clear that immigration policy became intertwined with national security, as most of the laws passed directly impacted illegal immigration from Mexico.

\footnotetext{
132 "Deaths in World Trade Center Terrorist Attacks --- New York City, 2001." Centers for Disease Control and Prevention. Centers for Disease Control and Prevention, September 11, 2002. https://www.cdc.gov/mmwr/preview/mmwrhtml/mm51SPa6.htm.
} 
The national security skyline has changed for the United States since September 11, 2001. Although changes have been made to toughen the Visa Waiver Program, it can be argued that the United States was still vulnerable because of how applicants were vetted under VWP regulations. All of the 19 terrorists who were directly involved in the 9/11 attacks would have still be cleared to enter the United States years after 2001 because they all came from countries protected by the Visa Waiver Program. Fifteen of the 19 hijackers were citizens of Saudi Arabia while the others were from the United Arab Emirates, Egypt, and Lebanon. Even Zacarias Moussaoui, who was convicted and sentenced to six life terms in 2006 as a terrorist conspirator, entered the United States as a French citizen through the Visa Waiver Program.

Following $9 / 11$, new screening systems and databases were quickly developed to make it easier to link biographic, immigration, and criminal histories for applicants. This resulted in a new level of cooperation among federal, state, and local law enforcement agencies. ICE also played a major role in the new policies in the Visa Security Program, which vets individuals against intelligence data and terrorist watch lists. Other visa programs like the U.S. Visitor and Immigration Status Indicator Technology program, the Student and Exchange Visitor Information System, and the Electronic System for Travel Authorization have promoted a new generation of agency cooperation to help limit domestic terrorism.

The terrorists who committed these heinous acts entered with student and visitor visas through the Visa Waiver program, thus immigration processes became the immediate topic of concern in the aftermath. The public debates and those in Congress intertwined the concepts of national security and immigration. This was expected as those 
who committed the terrorist attacks on 9/11 entered the United States through the immigration system. If there were stricter immigration policies, would these terrorists have been able to enter into the United States? There is no way of knowing, but it is safe to say that it would have been more difficult for them to do so. There were five momentous national security measures that also affected immigration in critical ways over the next four years: 1) The Anti-Terrorism Act of 2001, ${ }^{133}$ 2) The United and Strengthening America by Providing Appropriate Tolls Required to Intercept and Obstruct Terrorist Act of 2001, known as the Patriot Act, ${ }^{134}$ 3) the Enhanced Border Security and Visa Entry Reform Act (EBSVERA) ${ }^{135} 4$ ) the Homeland Security Act of $2002,{ }^{136}$ and 5) the Intelligence Reform and Terrorism Prevention Act (IRTPA). ${ }^{137}$

This chapter will first look at the illegal immigration statistics post-9/11. Because there was a larger public focus on national security, was there some implication on the number of illegal immigrants who entered the country? Following this statistical analysis, the chapter will further look at the five major national security measures after 9/11. It will analyze the implementation of such polices that subsequently led to the continuous increase of illegal immigrants. Following this analysis, the chapter will look at a few other initiatives, including the Secure Border Initiative. This chapter will also analyze how Border Patrol changed following 9/11, and will conclude by looking at the Secure

\footnotetext{
${ }^{133}$ Administration's Draft Anti-Terrorism Act of 2001, 107th Cong., 1st sess., September 24, 2001 , http://commdocs.house.gov/committees/judiciary/hju75288.000/hju75288 0f.htm.

${ }^{134}$ The USA PATRIOT Act of 2001, Pub. L. 107-56, 107th Cong., 1st sess., (October 26, 2001).

${ }^{135}$ Enhanced Border Security and Visa Entry Reform Act of 2002, Pub. L. No. 107-173, 107th Cong., 2nd sess. (March 12, 2002).

${ }^{136}$ The Homeland Security Act of 2002, Pub. L. 107-296, 107th Congress, 2nd sess., (November 25, 2002), www.dhs.gov/xlibrary/assets/hr_5005_enr.pdf.

${ }^{137}$ Intelligence Reform and Terrorism Prevention Act of 2004, Pub. L. 108-458, 108th Cong., 2nd sess., (December 17, 2004), http://intelligence.senate.gov/laws/pl108-458.pdf.
} 
Fence Act of 2006. These topics will be analyzed through the lens of change following the September $11^{\text {th }}$ terrorist attacks.

\section{Illegal Immigration following 9/11 Terrorist Attacks}

With all of these immigration and national security measures, it would be expected that illegal immigration would have drastically decreased in the years following 2001. When looking at the data, it is clear that illegal immigration was not affected by these "national security" measures. A record number of illegal immigrants entered the country in the five years following $9 / 11$.

Table 4- Country of Birth of the Illegal Immigrant Population: January 2000 and 2005 (in thousands)

\begin{tabular}{|c|c|c|c|c|c|c|}
\hline \multirow[t]{2}{*}{ Country of Birth } & \multicolumn{2}{|c|}{$\begin{array}{c}\text { Estimated } \\
\text { Population in } \\
\text { January }\end{array}$} & \multicolumn{2}{|c|}{$\begin{array}{c}\text { Percent of } \\
\text { Total }\end{array}$} & \multirow{2}{*}{$\begin{array}{c}\begin{array}{c}\text { Percent } \\
\text { Change }\end{array} \\
2000 \text { to } \\
2005\end{array}$} & \multirow{2}{*}{$\begin{array}{c}\text { Average } \\
\text { Annual } \\
\text { Change } \\
2000 \text { to } \\
2005\end{array}$} \\
\hline & 2000 & 2005 & 2000 & 2005 & & \\
\hline All Countries............... & 8,460 & 10,500 & 100 & 100 & 24 & 408 \\
\hline Mexico & 4,680 & 5,970 & 55 & 57 & 28 & 258 \\
\hline ................ & 430 & 470 & 5 & 4 & 9 & 8 \\
\hline El Salvador...... & 290 & 370 & 3 & 4 & 28 & 16 \\
\hline Guatemala................ & 120 & 280 & 1 & 3 & 133 & 32 \\
\hline India & 190 & 230 & 2 & 2 & 21 & 8 \\
\hline & 180 & 210 & 2 & 2 & 17 & 6 \\
\hline China...................... & 200 & 210 & 2 & 2 & 5 & 2 \\
\hline Korea...................... & 160 & 180 & 2 & 2 & 13 & 4 \\
\hline Philippines............... & 100 & 170 & 1 & 2 & 70 & 14 \\
\hline Honduras................ & 160 & 160 & 2 & 2 & - & - \\
\hline Brazil................... & 1,950 & 2,250 & 23 & 21 & 15 & 60 \\
\hline $\begin{array}{l}\text { Vietnam.................. } \\
\text { Other countries......... }\end{array}$ & & & & & & \\
\hline
\end{tabular}

s. Department of Homeland Security, 2016

The increase in illegal immigration could illustrate that the initiatives passed were a failure. If five major national security/illegal immigration policies were unable to stop 
illegal immigrants from coming into the United States, how could it be believed that they stopped any terrorists from entering into the country? The table illustrates that the largest portion were still coming from Mexico. Was nothing implemented during this time to prevent illegal immigrants from coming over the United States-Mexico border? To assess this issue, it is necessary to understand what policies were passed immediately following 9/11. In addition to the number of illegal immigrants who entered the country, it is also important to look at the numbers of illegal immigrants who were removed or returned.

Table 5 - Removals and Returns 2000 to 2005

\begin{tabular}{|l|l|l|}
\hline \multicolumn{1}{|c|}{ Year } & \multicolumn{1}{c|}{ Removals } & \multicolumn{1}{c|}{ Returns } \\
\hline 2000 & 188,467 & $1,675,876$ \\
\hline 2001 & 189,026 & $1,349,371$ \\
\hline 2002 & 165,168 & $1,012,116$ \\
\hline 2003 & 211,098 & 945,294 \\
\hline 2004 & 240,665 & $1,166,576$ \\
\hline 2005 & 246,431 & $1,096,920$ \\
\hline
\end{tabular}

s. Department of Homeland Security, 2016

When analyzing both tables, it is important to note that the number of removals increased while the number of returns decreased. Does this mean that there was an improvement in border security after 9/11? But then why did the total number of illegal immigrants continue to rise? There was legislation that was passed following 9/11, however it did not contribute to the number of illegal immigrants in the United States. Both of these tables illustrate that although there was a focus on national security, policies aimed at strengthening the border should be deemed unsuccessful, as they did not prevent the number of illegal immigrants from entering into the United States.

The number of removals increasing does show that there was a greater focus in deporting illegal immigrants that were already in the United States. However, the total 
number of illegal immigrants continued to increase from 2000 to 2005 . There are two possible reasons for this. First, there was a higher increase of visa overstays in the United States from 2000 to 2005 . The second hypothesis is that illegal immigrants were getting more creative and finding new routes into the United States without getting detected. Let's first look at the number of visa overstays from 2000 to 2005. The Department of Homeland Security does not have a precise number of visa overstay, because it is almost impossible to exactly know how many leave or how many stay without telling the government. There have been some studies to estimate the number of illegal immigrants who might have overstayed their visa by looking at the net growth, but all of those numbers are just estimates.

To check the hypothesis of illegal immigrants taking new paths into the United States, the number of illegal immigrant deaths trying to cross the border is an essential statistic. The U.S. Border Patrol reported an increase of deaths in the Southwest Border, which could indicate that illegal immigrants were attempting more difficult paths into the country because of the increased focus on national security. In 2000, there were 380 deaths in the Southwest Border, which increased to 492 in $2005 .{ }^{138}$ There was a decrease in the San Diego sector, but an increase in the Tucson area. This indicates that illegal immigrants were taking the more difficult paths through the desert. The increase of illegal immigrants and the decreasing number of returns indicates that the policies passed were not effectively enacted. In order to understand why the policies were unable to prevent the rising number of illegal immigrants, it is important to analyze the policies themselves.

\footnotetext{
${ }^{138}$ United States Border Patrol. Southwest Border Deaths By Fiscal Year. Raw data. Southwest Border Sectors.
} 
Anti-Terrorism Act of 2001 and the Patriot Act

Eight days following the 9/11 attacks, President Bush and his administration submitted to Congress the Anti-Terrorism Act of 2001. The goal of this legislation was to expand the authority to gather domestic intelligence, combat the money laundering that is used in terrorist financing, and to expedite the judicial procedures to deport suspected terrorists. This initial proposal had backlash, as some legislators opposed parts of the Act that would allow for the indefinite detention of noncitizens. But with the Bush administration pushing for an expedited judicial procedure and indefinite detention, the United and Strengthening America by Providing Appropriate Tools Required to Intercept and Obstruct Terrorism Act of 2001, known as the USA PATRIOT Act, passed in October 2001 with near unanimous support in both chambers. ${ }^{139}$ The Patriot Act passed in the House with a 356 to 66 vote, while also in the Senate with a 98 to 1 vote.

Following 9/11, Congress and the Bush administration placed a new importance on immigration, even though there was a focus on immigration policy prior to the terrorist attacks. Instead of building the relationship with Mexico and other foreign countries, there was an emphasis on securing the borders to prevent future terrorists from entering into the United States. Although the terrorists did not enter through the U.S.Mexican border and were not from Mexico, Mexican immigrants felt a large burden from the Patriot Act. The mission of the Patriot Act is to "deter and punish terrorist acts around the world [and] to enhance law enforcement investigatory tools. ${ }^{140}$ The Patriot Act limits

\footnotetext{
${ }^{139}$ Uniting and Strengthening America by Providing Appropriate Tools Required to Intercept and Obstruct Terrorism Act of 2001 (USA PATRIOT Act). Pub. L.No. 107-56. §§ 412. 201-25. 115 Stat. 272. 278-96. 350-52 (2001)

${ }^{140} I d$.
} 
the phrase "national security." Instead, the terms "terrorism" and "terrorist acts" are used. The Patriot act expanded the definition of "terrorist activity" that allowed for the removal of illegal immigrants convicted of assault and similar crimes.

The term "terrorism" is difficult to define. Does terrorism include domestic crimes like murder or assault? At what point is mass murder considered terrorism? This confusion in the definition created many questions regarding the Patriot Act. The Act does define "domestic terrorism" as crimes that involve endangering human lives, which intended to either intimidate the civilian population or to influence government policy by intimidation or coercion, or to affect the workings of government by mass destruction, assassination, or kidnapping. ${ }^{141}$ However, "terrorist activity" included those who were charged with an "aggravated felony." This is not what one normally associates with the concept of "terrorism." Illegal immigrants who were committing crimes that would not be considered "normal" terrorist activities were grouped into the same category as those criminals conducting typical terrorist crimes. The Patriot Act also made a spouse or child of such "terrorists" inadmissible. An illegal immigrant may also be deemed inadmissible for being "associated to a terrorist organization," which is a broad term and creates a guilty by association scenario. ${ }^{142}$ The Patriot Act also increased funds for enforcement of the U.S./Canada border.

The main criticisms of the Patriot Act are related to the expansion of government powers that extend farther than needed, which infringe on constitutional rights. The Patriot act added government surveillance powers. It allowed wiretap orders to be allowed for a wider range of suspected crimes. The Patriot Act also created "sneak and

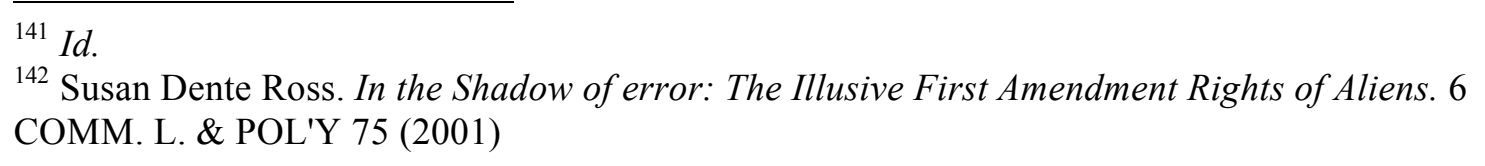


peek" search warrants. Usually there was a notice of a search warrant in order to permit the subject of the search to invoke their Fourth Amendment rights, like being able to point out the deficiencies in the warrant, which gives protection against "unreasonable searches and seizures," however the Patriot Act eliminated such notice. The Patriot Act allowed voicemails to be seized, instead of only allowing a wiretap. All of these provisions were also aimed at non-violent crimes like computer offenses, which was heavily criticized. "Sneak and Peek" warrants created concern because of the ability to use them in non-terrorism cases, including illegal immigration cases.

The most important contribution of the Patriot Act to illegal immigration is the mandatory detention until deportation of "certified" aliens "suspected of terrorist involvement," which is Section 412 of the Act. Under that section, the Attorney General may permanently detain an illegal immigrant if he/she has "reasonable grounds to believe" the alien endangers U.S. national security. ${ }^{143}$ Before the Patriot Act, it was very specific in why an illegal immigrant could be excluded or deported, like an attempt to overthrow the government or terrorist activities, with almost not interpretation needed. Now, the Attorney General interpreted the law, and had the power to deport an illegal immigrant based on "reasonable grounds to believe" he/she endangers national security. However, if the Attorney General certifies an illegal immigrant, meaning the illegal immigrant fits the categories that were expanded by the Patriot Act like being associated with an extremist group or commits a crime against national security, the illegal immigrant must be taken into custody. Within seven days of the detention, the Attorney General must place the alien in removal proceedings or charge them with a criminal

\footnotetext{
${ }^{143}$ US Patriot Act, supra note 139, at Section 412(a)(3) of the USA Patriot Act, codified at 8 U.S.C. $1226 a(a)(3)(2001)$
} 
offense. If there is not any immigration or criminal charge filed, the illegal immigrant must be released. The Patriot Act says, "Detention ends if the alien is determined not to be removable." This section also includes specifics on what to do with an illegal immigrant who has been certified by the Patriot Act who has not been deported within 90 days. This section allows an extended duration of detention for additional six-month periods "only if the release of the alien will threaten the national security of the United States or the safety of the community or any person"144

Prior to these changes in Section 412, illegal immigrants that were suspected of terrorism could be arrested based on terrorist offenses. The INS had discretion to decide whether an illegal immigrant should be released on bail or not, depending if they are a risk to national security or there is a risk they would miss the immigration hearings. "Under the new law, detention is mandatory for aliens certified by the Attorney General, and any alien that the government has 'reasonable grounds to believe' meets any of the broad grounds for inadmissibility or deportation in section 412 , or is otherwise considered a national security threat, may be certified ... Certified aliens are automatically ineligible for bail; there is no opportunity for an adversarial hearing to contest their detention. In sum, section 3412 introduces an irrefutable presumption that aliens subject to certification are unfit for release."145

The major question that was asked by U.S. citizens and politicians was whether the Act constitutes the most relevant and appropriate response to the threat of terrorism. Section 412 was the way the Patriot Act affected illegal immigrants from Mexico, and

\footnotetext{
${ }^{144} I d$. at 412(a)(6), 8 U.S.C. $1226 \mathrm{a}(\mathrm{a})(6)$

${ }^{145}$ Sinnar, S. (2003). Patriotic or Unconstitutional? The Mandatory Detention of Aliens under the USA Patriot Act. Stanford Law Review, 55(4), 1419-1456. Retrieved from http://www.jstor.org.libproxy.chapman.edu/stable/1229608
} 
may have been a contributing factor to the reasons why there was an increase in removals from 2000 to 2005 .

\section{The Enhanced Border Security and Visa Entry Reform Act}

Within four months of passing the Patriot Act, Congress passed the Enhanced Border Security and Visa Entry Reform Act (EBSVERA), signed into law in May of 2002. ${ }^{146}$ This legislation is one of the most comprehensive legislation aimed at illegal immigration passed in response to the 9/11 terrorist attacks. The EBSVERA focused on securing the borders by providing funding to do so. There are three main points of this act that are most important in improving the United States ability to control the borders. These include: 1) the requirement that the INS make an internal database that would allow an illegal immigrant be found with one single search, 2) the requirement that federal law enforcement and other intelligence agencies share data regarding illegal immigrants with the INS and state department, and 3) the requirement that travel and entry documents like visas, be machine-readable and tamper-resistant. The EBSVERA also initiated an increase of 3,000 immigration inspectors and investigators. ${ }^{147}$

Although the Enhanced Border Security and Visa Entry Reform Act may have immediately helped with illegal immigration, many of the deadlines mandated by Congress took many years to be implemented. One reason for this is because of the Homeland Security Act, which created much confusion and chaos within the government. In the Enhanced Border Security and Visa Entry Reform Act, a deadline of 15 months

\footnotetext{
${ }^{146}$ H.R. 3525, 107th Cong. (enacted).

${ }^{147}$ H.R. 3525, 107th Cong. (enacted).
} 
was included for the illegal immigration reforms. ${ }^{148}$ However, as of December 1, 2003, there were nine of the required reforms in the Reform Act that had not passed yet, where four of those nine were implemented long after the deadlines. ${ }^{149}$ By 2005 , the nine reforms were not enacted yet.

One of the most important reforms that was passed by EBSVERA was the creation of an integrated data system, which was referred to as Chimera. This system was supposed to include biometric identifiers, immigration and law enforcement records, and intelligence information on every applicant. Before 9/11, the INS had multiple systems that were not compatible with each other, even with other law enforcement agencies like the FBI. For example, the INS had individual databases for criminal/illegal immigrants, for naturalization applicants, and for lawful immigrant residents. ${ }^{150}$ This lack of communication is one of the reasons why $9 / 11$ happened. Khalid al Midhar, who was one of the terrorists on American Airlines Flight 77 was identified by the CIA as a terrorist on January 2001. But because the databases were separate from the INS, he was admitted into the United States in August of 2001. This system was never created by the United States, which illustrates some of the failed policies following 9/11. Although this integrated system that was passed stalled, there were improvements with information sharing. Following the creation of the DHS, an interim system was implemented that allows for easier searches in the CIA and DHS systems.

\footnotetext{
${ }^{148} I d$.

${ }^{149}$ Camarota, Steven A., and Rosemary Jenks. "Implementation of the Enhanced Border Security and Visa Entry Reform Act of 2002." Center for Immigration Studies. December 1, 2003. https://cis.org/Report/Implementation-Enhanced-Border-Security-and-Visa-Entry-Reform-Act2002.

${ }^{150} I d$.
} 
The Enhanced Border Security and Visa Entry Reform Act of 2002 would have significantly improved the security of the visa process if it was fully implemented. Many aspects of this legislation were not, which illustrates the increase of illegal immigration during this time. The main reason why many of the pieces of this legislation were not implemented was because of the complexity of the Homeland Security Act that was passed just six months later.

\section{The Homeland Security Act of 2002}

The Homeland Security Act was passed on November 25, 2002, and established the United States Department of Homeland Security, one of the most important acts passed during that era. ${ }^{151}$ The primary mission of the Homeland Security Act is to "prevent terrorist attacks within the United States, reduce the vulnerability of the United States to terrorism, and minimize damage and assist in recovery for terrorist attacks that occur in the United States." ${ }^{152}$ The Homeland Security Act brought together all of the 22 federal agencies and 170,000 federal employees into a new agency, called the Department of Homeland Security (DHS). ${ }^{153}$ This was the largest and most complex reorganization of the federal government since the Department of Defense was created after World War II. Although the concluding chapter will argue President Bush should have taken advantage of this time to effectively implement policies to limit the number of illegal immigrants, he did take full advantage of the time to implement personnel reform in the federal government.

${ }^{151}$ The Homeland Security Act of 2002, Pub. L. 107-296, 107th Congress, 2nd sess., (November 25, 2002), www.dhs.gov/xlibrary/assets/hr_5005_enr.pdf.

${ }^{152} I d$. ${ }^{153} I d$. 
This personnel reform allowed Bush to appoint colleagues to positions in the DHS, like Pennsylvania governor Tom Ridge as the president's senior advisor. Merging 22 different agencies posed many challenges, as there were 17 different unions, 77 existing collect bargaining agreements, 22 human resources servicing office, and eight payroll systems. Representative Rob Portman, then a member of the House Select Committee on Homeland Security, stated how "It's absolutely critical, if this department is going to work, that the President be able to take the 22 different personnel systems ... and meld them together in a way that we ... make an effective agency to combat terrorism. The agility of the terrorist needs to be matched by a more agile federal workforce. $" 154$

Although there were many complaints with how the Act was written, and even though there seemed to be a lot of logistical issues, because it was within a year of the terrorist attacks, the phrase "national security" was very powerful. This is an example of a piece of legislation that passed because of the rhetoric towards preventing another $9 / 11$ attack. "Administrative reform emerges and is successfully enacted when the timing is right and opportunity is recognized. Otherwise, the imperative for change can be lost to other more pressing priorities." 155 This concept will be used heavily in the conclusion to argue how both Presidents Clinton and Bush could have enacted more efficient illegal immigration reform policies. The Homeland Security Act of 2002 is a perfect example of this. One of the agencies in the Homeland Security Act that directly affected the focus on the border was the creation of ICE. However, there was little effectiveness by this

\footnotetext{
${ }^{154}$ Congressman Portman, Rob. "Homeland Security Legislation." Interview by Margaret Warner. PBS.

${ }^{155}$ Brook, D., \& Cynthia L. King. (2007). Civil Service Reform as National Security: The Homeland Security Act of 2002. Public Administration Review, 67(3), 399-407. Retrieved from http://www.jstor.org.libproxy.chapman.edu/stable/4624582
} 
department until many years later because of the newness of the department. This is one reason why the number of removals increased by 35 percent from 2002 to 2003. Although the reorganization was a major change with the Department of Homeland Security, there was a significant change with the mission of the DHS and Border Patrol post 9/11. The INS mission was focused on preventing illegal immigrants from entering the United States. The DHS's mission is focused on national security. This is a major difference when comparing two departments focused on illegal immigration, because now border patrol has to worry about preventing not only an illegal immigrant into the country, but must be worried about preventing a terrorist from entering. The mission of the Homeland Security is "to ensure a homeland that is safe, secure, and resilient against terrorism and other hazards. ${ }^{156}$ From that statement alone, it is evident that terrorism and national security play an important role in the decisions of illegal immigration. Prior to the DHS, the INS was solely focused on preventing illegals from coming into the United States, without the joint mission of terrorism. The focus on terrorism is an important shift, because it drastically increases the responsibility of the DHS.

The Intelligence Reform and Terrorism Prevention Act The final major legislation that Congress passed was the Intelligence Reform and Terrorism Prevention Act (IRTPA). This legislation was approved 96-2 in the Senate and

\footnotetext{
156 "Our Mission." Department of Homeland Security. May 11, 2016. https://www.dhs.gov/ourmission.
} 
336-75 in the House, and was signed by President Bush on December 17, 2004. ${ }^{157}$ This law established the position of Director of National Intelligence, the National Counterterrorism Center, and the Privacy and Civil Liberties Oversight Board. The IRTPA mainly addressed the 9/11 Commission's recommendations to create an Office of the Director of National Intelligence and also to fund additional surveillance and border enforcement.

The IRTPA was not as significant as the Patriot Act or The Homeland Security Act, however it illustrates the number of laws that were proposed and passed by Congress. This illustrates the focus on national security, and the ability the United States government had to pass strict immigration policies that would eliminate the issues of illegal immigration once and for all. Section V of the IRTPA was titled "Border Protection, Immigration, and Visa Matters." Section 5102, part A states:

"The Secretary of Homeland Security shall design the pilot program under this subtitle to have the following features:

1) Use of advanced technological systems, including sensors, video, and unmanned aerial vehicles, for border surveillance,

2) Use of advanced computing and decision integration software, 3) Testing of advanced technology systems and software to best and most cost-effective uses of advanced technology to improve border security, 4) Operation of the program in remote stretches of border lands with long distances between 24-hour ports of entry with a relatively small presence of United States border patrol officers,

5) Capability to expand the program upon a determination by the Secretary that expansion would be an appropriate and cost-effective means of improving border security." 158

\footnotetext{
${ }^{157}$ Peters, Gerhard; Woolley, John T. "George W. Bush: "Statement on Signing the Intelligence Reform and Terrorism Prevention Act of 2005," December 17, 2005". The American Presidency Project. University of California - Santa Barbara.

${ }^{158}$ S. 2845, 107th Cong. (2004) (enacted).
} 
The IRTPA gave Homeland Security more tools and resources to be able to patrol the border. It allowed for the use of technology that would improve the ability to prevent illegal immigrants from entering into the United States. There was little controversy regarding this policy, illustrating that there was unanimous support for this legislation and other legislation to prevent illegal immigration. The issue became the implementation of all of these new policies, because as shown, the number of illegal immigrants continued to rise from 2000 to 2005 , even with these laws passed.

The U.S. Relationship with Mexico following 9/11

Following the terrorist attacks on 9/11, illegal immigration was viewed through a different lens. Instead of being illegal immigrants trying to enter the country to seek a better life, it became possible terrorists trying to enter the country to commit national terror. It is obvious that the relationship with Mexico was going to change following 9/11. The developing relationship between Vicente Fox and George W. Bush drastically changed because of the vulnerability felt by the United States at its borders. Although none of the 9/11 terrorists entered the country through Mexico, what stopped the next terrorist from doing so? This mindset created a major change, where "immigration, as with all policy issues, is now viewed through a security lens. Security is the utmost priority and security-related issues have replaced all others at the top of Washington's agenda. Any immigration proposals that resurface on the political agenda, such as regularization of status or issuance of student visas, will be geared toward this overriding policy concern. Given the personal and political capital that Presidents Bush and Fox 
have invested in the relationship between the two countries even prior to September 11, it is important to note that the United States has created an additional standard for friendship: the degree to which another state cooperates — in fact, partnersin the war against terrorism."159

The discussion before the terrorist attacks on $9 / 11$ were focused on the legalization process of Mexican immigrants, and figuring out the best way to safeguard those immigrants entering into the United States, while even questioning if it is best to open the borders completely. On the morning of September $11^{\text {th }}$, Bush was envisioning a bright future with Mexico. Fox had just left from a progressive meeting where they strengthened their relationship, as it promised electoral dividends for Bush. Immediately following the terror attacks, Fox was almost forgotten about, as national security from terrorism became the main priority. In two national polls after September $11^{\text {th }}$, roughly 80 percent of Americans concluded that it was "too easy" for foreigners to enter the country. "In Congress talk of amnesty for illegal aliens yielded a scramble to plug porous borders and keep track of the movements of foreigners. The meetings of U.S.-Mexico High Level Working Group on Migration, headed on the U.S. side by Secretary of State Colin Powell and Attorney General John Ashcroft, were suspended. When they resumed in January, the urgency was gone; the pace and the dynamics had changed."160

There were some attempts for progress with the U.S.-Mexico relationship. In March of 2002, the two countries singed a "Smart Border" declaration stating that

\footnotetext{
${ }^{159}$ Deborah Waller Myers and Demetrios G. Papademetriou, "The US-Mexico Immigration Relationship: Operating in a New Context by Setting the Stage," Foreign Affairs en Español, Spring 2002.

${ }^{160}$ National Public Radio, the Kaiser Family Foundation and the Harvard University Kennedy School of Government in November found that "the number of Americans wishing to decrease immigration has risen dramatically, from 41 percent in June 2001 to 61 percent...." (http://www.kff.org/content/2001/3209/CivilLibertiesFinalSummary.pdf).
} 
...the international campaign to eradicate terrorism requires us to address pressing new priorities and shared goals central to defending our societies and ways of life. At the same time, we recognized that the events of September 11 underscore more than ever the importance of the U.S.Mexican relationship, as partners and neighbors, in the attainment of those goals and in realizing the vision we have set forth for our countries' future...We will build a border that protects our societies against those who would do us harm, and that truly serves the human and economic needs of our dynamic relationship. ${ }^{161}$

The two nations also launched "Partnership for Prosperity," which was aimed to "leverage private resources to create jobs and promote prosperity in less developed areas of Mexico." This pact would create capital for small companies, and create scholarship programs for Mexicans to attend college in the U.S.

With regards to bilateral migration negotiations, there had been a lot of discussions regarding making the legalization process more efficient and effective. These discussions included an earned legalization program for illegal immigrants and a new temporary worker program that would bring workers from Mexico to fill employment gaps. There was a growing frustration following $9 / 11$, as the legalization process for Mexican immigration was not a top priority for the United States. This frustration was especially present after the United States refused to appoint a chief negotiator. Mexican Foreign Minister Jorge Castaneda resigned in January of 2003 because of the lack of negotiations and progress by the U.S. Although immigration was a priority for the United

${ }^{161}$ Joint U.S.-Mexico Statement, Monterrey, Mexico, March 22, 2002. 
States, it was more oriented towards national security and terrorism, not a comprehensive immigration reform to legalize Mexican immigrants.

Although these attempts seem earnest, it is clear there is a declining relationship between the countries. The Mexican government has taken steps that have angered the U.S. In August of 2002, President Fox declined an invitation by Bush to a summit because he was protesting the execution of a convicted murderer who was a Mexican national. Also, on January 21, 2003, Mexico asked the International Court of Justices to prevent the executions of 51 Mexicans on death row in the U.S. ${ }^{162}$ They claimed that there was a violation of international law when the U.S. failed to inform consular officials when Mexican migrants were arrested or sentenced. Mexico also filed a separate suit against the U.S. with the InterAmerican Human Rights Court of the OAS, saying that the U.S. treatment of migrant workers is in violation of international law. ${ }^{163}$ The combination of these law suits, along with anti-immigrant groups illustrating how illegal immigration is a national security threat left President Bush and the American public leery of a deal with Mexico.

There was also a strain with Bush and Fox over the different opinions on Iraq. Fox also had anti-war beliefs, as he was the first country to formally withdraw from the Inter-American Treaty of Reciprocal Assistance, or the Rio Treaty, to protest the U.S. intention to invade Iraq. Mexico is a nonpermanent member of the U.S. Security Council, and held an important vote on Iraqi policy. In the fall of 2002, Mexico lobbied with France to have the U.N. conduct weapons inspections in Iraq before war.

162 "Half an Enchilada: Mexico and the United States." The Economist, January 23, 2003.

163 "Mexico Takes Problem of Migrant Workers to OAS Tribunal." Associated Press, February 24, 2003. 
As illustrated, the attacks on 9/11 strained the relationship between the United States and Mexico, even though Mexico did not play a role in the attacks. The attacks shifted the focus of U.S. policies, changed the rhetoric from helping Mexican immigrants enter the country legally to preventing terrorists/illegal immigrants, following $9 / 11$ they seem to be categorized the same, from entering the United States.

\section{Border Patrol and the Secure Border Initiative}

It would be expected that there would be a drastic increase in the number of border patrol agents following 9/11. However, the mission and goals changed, not the number of agents. The rate of growth for border agents was actually higher in the years prior to $9 / 11$ than the years following. One reason behind this was that there was a focus on other aspects of border patrol, like the equipment used for surveillance. In the four years proceeding 9/11, full-time Border Patrol agents increased from 6,817 in 1997 to 9,651 in 2001, which is a 42 percent increase. ${ }^{164}$ By comparison, in the four years following the attacks, they increased from 9,902 in 2002 to 11,106 in 2005, an increase of only 15 percent. ${ }^{165}$ Although there may have been a focus on making the border more effectively patrolled, the budget drastically increased the years following 9/11 to strengthen security. The percent of border agents along the Mexican border compared to the Canadian border is stark. In 2001, for example, 93.9 percent of the agents were located along the border with Mexico. In 2005, 88.8 percent were assigned to this border. In 2001, 3.4 percent of the agents were along the border with Canada, which rose to 8.8 percent in $2005 .^{166}$

\footnotetext{
${ }^{164}$ Transactional Records Access Clearinghouse, Syracuse University, 2006.

${ }^{165} I d$.

${ }^{166} I d$.
} 
As previously stated, the number of illegal immigrants continued to increase following 9/11. This cat and mouse like game of illegal immigrants and border patrol did not change after the terror attacks. The number of apprehensions by border patrol decreased during the years following $9 / 11 .{ }^{167}$ This means that illegal immigrants were entering through less traveled, more dangerous areas. The most significant change for the border patrol was the inclusion of ensuring future terrorists did not enter the country. Although there was a major focus on drug control and making sure illegal immigrants did not enter the country, there was an increased suspicion because of this.

In the immediate years following $9 / 11$, the policies were aimed at strengthening the border through national security measures. However, it was not until 2005 when the DHS launched the Secure Border Initiative (SBI), which was described by DHS Secretary Michael Chertoff as "a comprehensive multiyear plan to secure America's borders and reduce illegal migration." Although legislation was passed creating the DHS, along with increasing funding to border control, this initiative was the first attempt to actually increase border security. SBI's goal was to organize the four components of border security, including Customs and Border Protection, Immigration and Customs Enforcement, U.S. Citizenship and Immigration Services, and the U.S. Coast Guard.

The three goals of SBI was to improve border security, increase interior enforcement of immigration and custom laws, and implement a temporary worker program. However, there were many issues with the implementation of this multiyear, multibillion-dollar program aimed at securing the borders and reducing illegal immigration. The United States Government Accountability Office (GAO) in a report to

\footnotetext{
${ }^{167}$ U.S. Border Patrol Monthly Apprehensions (FY 2000 - FY 2018). U.S. Customs and Border Protection. Department of Homeland Security.
} 
the Committee on Homeland Security and Governmental Affairs found that SBInet, which refers to "surveillance technologies, such as sensors, cameras, and radars, as well as command, control, communications, and intelligence (C3I) technologies, including software and hardware to produce a Common Operating Picture (COP)," that "since the inception of SBInet, GAO has reported on a range of issues regarding design and implementation, including program challenges, management weaknesses, and cost, schedule, and performance risks... for example, in October 2007, we testified that DHS had made some progress in implementing Project 28 - the first segment of SBInet technology across the southwest border—but had fallen behind its planned schedule."168 The SBI was aimed at deploying over 300 miles of single-layer fencing. But as of April 2010, "SBInet's promised technology capabilities are still not operational and delays continue to require Border Patrol to rely on existing technology for securing the border, rather than using the newer SBInet technology planned to overcome the existing technology's limitations. When CBP initiated SBInet in 2006, it planned to complete SBInet deployment along the entire southwest border in fiscal year 2009, but by February 2009, the completion date had slipped to 2016."169 Although the initiatives of SBInet seemed true, the implementation of these policies was not effective. As of 2010, the technology used by border patrol had issues, like cameras losing signal. This may be one reason why the number of apprehensions decreased, because when illegal immigrants decided to enter through Arizona where there had initially been less protection, the equipment used failed.

\footnotetext{
${ }^{168}$ United States. United States Government Accountability Office. SECURE BORDER INITIATIVE: DHS Has Faced Challenges Deploying Technology and Fencing Along the Southwest Border. Richard M. Stana. Statement for the Record to the Committee on Homeland Security and Governmental Affairs, U.S. Senate ${ }^{169} I d$.
} 


\section{Secure Fence Act of 2006}

It was not until 2006 that President Bush decided it was time to strengthen the border with an actual border. It took five years after $9 / 11$ for the administration to realize that illegal immigrants continued to enter the country at high rates, and that something needed to be done. The Secure Fence Act of 2006, H.R. 6061, partially funded the construction of 700 miles of fencing. This act was in conjunction with the SBInet, as it seemed that SBInet was more focused on the technology of the border, not the border itself. Bush signed the act into law on October 26, 2006, and stated that the act would "help protect the American people" and would "make our border more secure."170

Although the Secure Fence Act was passed in 2006, it was not until 2009 that the DHS erected over 600 miles of fencing. Although the initial act required the DHS to construct two-layered fencing, the Act allowed the discretion of the DHS in where the fence needs to be two-layer. Although 600 miles may seem like a significant part of the border, it is approximately only a quarter of the length of the U.S-Mexican border.

Similarly to Operation Gatekeeper, this act seemed to only push immigrants to other entry points. The freedom that the Secure Fence Act gave the DHS led to a single fence being constructed, which did little from preventing illegal immigrants from entering. This wall that was erected in 2009 from the Secure Fence Act did not stop illegal immigrants from entering, illustrating the poor effort of construction. The difference between the fence that was constructed during Operation Gatekeeper and the fence from the Secure Fence Act was the height and width of the wall. Operation Gatekeeper was only the first 14 miles, however, the fence was over ten feet tall and had

\footnotetext{
170 "Fact Sheet: The Secure Fence Act of 2006". The White House.
} 
multiple layers. On the contrary, the fence that was built from the Secure Fence Act was not always as secure.

From 2005 all the way to 2010 , CBP increased the total miles of the southwest border from 119 miles to 654 miles. However, the Secure Fence Act only included 37 miles of secondary fencing. Also, only 354 miles is pedestrian fencing, like the normal wall one would expect. The other 300 miles is vehicle fencing, which is a type of fencing that involves large cement blocks and other means that would only stop a vehicle from entering. However, this type of border freely allows illegal immigrants to walk right into the country. The majority of the vehicle fencing is where illegal immigrants may be entering from, which is along the Arizona-Mexico border. There was success to these vehicle fences, as Border Patrol in the El Paso and Tucson sectors reported that "they experienced significant decreases in drive throughs following the deployment of vehicle fencing. Officials in the Tucson sector reported that vehicle fencing deployed improved Border Patrol agents' ability to impede and deny the entry of large amounts of illegal narcotics transported by motorized vehicles."171

There was a significant monetary cost to build 600 new miles of fence, even if half could not prevent individuals from walking across it. CBP reported that it cost a little more than $\$ 2$ billion and also estimated it would cost another \$1 billion to sustain this fence over the next 20 years.

\footnotetext{
${ }^{171}$ United States. United States Government Accountability Office. SOUTHWEST BORDER SECURITY Additional Actions Needed to Better Assess Fencing's Contributions to Operations and Provide Guidance for Identifying Capability Gaps. Report to Congressional Requesters. February 2017.
} 


\section{Conclusion}

Following the terrorist attacks on 9/11, sweeping initiatives were passed. The focus was on securing the borders to prevent future terrorists from entering the country. However, it is evident by the increasing number of illegal immigrants from 2000 to 2010 that the failure to implement the policies is to blame. Although it could be argued that even though there was an increase of illegal immigration, it was only a stepping-stone for future success. This argument proves that the initiatives failed at preventing illegal immigrants from entering the country during the immediate years after the terrorist attacks.

The Anti-Terrorism Act of 2001, The United and Strengthening America by Providing Appropriate Tolls Required to Intercept and Obstruct Terrorist Act of 2001, known as the Patriot Act, the Enhanced Border Security and Visa Entry Reform Act (EBSVERA), the Homeland Security Act of 2002, and the Intelligence Reform and Terrorism Prevention Act (IRTPA) all brought momentous changes. Although there were implementation failures with each initiative, it was the beginning of securing the borders. However, if these initiatives were unable to prevent illegal immigrants from entering the country, how could it be certain terrorists could not just as easily enter?

The goal of this chapter was to illustrate the number of laws and initiatives that were passed aimed at securing the border, yet with little to show for it. Instead of border security being about preventing non-citizens from entering, it became about preventing terrorists from entering. Illegal immigration is a national security policy because it is unknown who enters through the border when left unsecured. Although there was this change of mission, and change of governmental structure, little success came from it. The 
concluding chapter will look at policies from pre- and post-9/11, and argue that presidents Clinton and Bush failed to take advantage of their presidencies to effectively secure the borders. 


\section{CHAPTER 5}

"This is a day when all Americans from every walk of life unite in our resolve for justice and peace. America has stood down enemies before, and we will do so this time. None of us will ever forget this day, yet we go forward to defend freedom and all that is good and just in our world."

- President George W. Bush, 9/11 Address to the Nation, delivered on 11 September from the Oval Office, Washington D.C.

All Americans were shaken to their core with fear, confusion, and even anger when nearly 3,000 innocent men and women were killed in four coordinated terrorist attacks on the Pentagon, the crash of United Flight 93, and the collapse of the World Trade Center North and South towers in New York City on September 11, 2001.

Americans everywhere doubted their own safety and the safety of their family, friends, and the nation. They immediately demanded leadership by the federal government to prevent future homeland terrorist attacks. In reaction, the goals and missions of the three branches of the United States government changed dramatically following the attacks. But while there was an immediate and concentrated focus to improve future national security, it spawned many questions as to how past immigration laws should have prevented the devastation of September $11^{\text {th }}$. How could the United States have been so vulnerable to attacks by 19 hijackers affiliated with the Islamic terrorist group al-Qaeda? What role did President Clinton's immigration policies from his eight years in office factor into this attack on American soil?

In the aftermath of $9 / 11$ and with the urging of President Bush, Congress quickly passed numerous measures to improve national security that seemed a step in the right direction but were significantly flawed in policy and in their ability to be implemented. The question soon became: Was the United States really more secure from attacks than in 
the years before September 11? While Bush pushed ahead to protect the United States from foreign enemies abroad, Americans also became increasingly alarmed with the possibility of terrorists crossing the southern border through Mexico.

Illegal immigration now became a top-priority, national security issue. Borders were "tightened," yet illegal immigration continued to rise. Deportation laws were made more "efficient, yet there was only a slight increase in deportations in the five years following September $11^{\text {th }}$. More "effective" government organizations were formed, yet immigration reform was not effectively executed. Presidents Clinton and Bush both had chances during their terms to significantly lower illegal immigration. Clinton was elected and reelected during the 1990s when he supported the national sentiment to secure the southern border with Mexico, but yet his policies largely failed to limit the rising numbers crossing illegally. Bush had been in office less than eight months when the most deadly attack on American soil since Pearl Harbor took place, but it can be argued that Bush did not fully deliver on his promises to keep America safe since the flow of illegal immigrants significantly increased crime during his terms.

This chapter first explores the national costs associated with illegal immigration, and how Clinton and Bush essentially burdened the nation by not recognizing that illegal immigration had become both a major social and national security problem. The chapter will then look at several policies from both administrations and congressional measures to evaluate how they benefited the resolve to eliminate or at least decrease illegal immigration. Next is an analysis of which policies were successful and how other immigration issues were not fully addressed or became missed opportunities. Finally, the question of whether Clinton and/or Bush promoted effective illegal immigration laws, 
policies, and executive orders to fully secure the southern border is considered, and if they fulfilled their campaign promises to keep Americans safe. While both presidents clearly had opportunities to reform immigration, the greater question that all Americans can ask today is whether Clinton and Bush demonstrated effective presidential leadership in their efforts to permanently solve illegal immigration issues during their presidencies?

The Damage of Illegal Immigration: Why it should matter?

The question still remains: Why should Clinton and Bush have cared about illegal immigration? There are many different answers to this question, but the most reasonable one was and is the financial burden to Americans for the increasing numbers of illegal immigrants migrating into the United States each year. The Congressional Budget Office (CBO) did a study in 2007 that presented facts and research on the burden of illegal immigration. ${ }^{172}$ In this study, the $\mathrm{CBO}$ looked at different types of illegal immigrant costs, ranging from education, health care, and law enforcement. An important note on this study was that the $\mathrm{CBO}$ admitted that there was not an effective way of measuring the national costs of illegal immigrants, instead only state and local costs.

Illegal immigrants burden education costs because of the fact that their children are typically non-English speaking and require additional services that over-task local, state, and federal budgets. In 1982 the Supreme Court ruled that schools cannot turn away children because of their immigration status. ${ }^{173}$ In 2007, there was an estimated two million school children who are illegal immigrants, and another three million children

\footnotetext{
${ }^{172}$ Congressional Budget Office. The Impact of Unauthorized Immigrants on the Budgets of State and Local Governments, (2007). https://www.cbo.gov/sites/default/files/110th-congress2007-2008/reports/12-6-immigration.pdf.

${ }^{173}$ Plyler v. Doe, 457 U.S. 202 (1982).
} 
that are born to illegal immigrants after they arrived in the U.S. ${ }^{174}$ On the local level, the Pew Hispanic Center conducted a study for 2003-2004 and found that New Mexico state spent \$67 million for 9,200 illegal immigrant schoolchildren. Health Care is another significant cost because of illegal immigration. The federal government requires health facilities that receive federal assistance to provide service, regardless of their immigration status or their ability to pay for the help. In 2000, county governments that share a border with Mexico spent $\$ 190$ million in costs providing health care to illegal immigrants. ${ }^{175}$ Another significant cost by illegal immigrants is through law enforcement. Illegal immigrants who commit crimes are not immediately deported; they are instead processed through the local criminal justice system. In 2001, law enforcement activities involving illegal immigrants in counties that shared a border with Mexico, specifically in California, Arizona, New Mexico, and Texas, had a combined total of more than $\$ 108$ million additional costs than in $1999 .{ }^{176}$ In San Diego County alone, $\$ 50$ million was spent in 1999, which was nine percent of their total spending for law enforcement in that year. $^{177}$

Illegal immigration has always been an unwarranted cost to state and federal budgets and the American taxpayer. There are mized opinions, but research has shown

\footnotetext{
${ }^{174}$ Urban Institute, Children of Immigrants: Facts and Figures (Washington, D.C.: Urban Institute, 2006); and Passel, Unauthorized Migrants.

${ }^{175}$ MGT of America, Medical Emergency: Costs of Uncompensated Care in Southwest Border Counties (report prepared for the United States/Mexico Border Counties Coalition, September 2002), available at www.bordercounties.org.

${ }^{176}$ Salant, Tanis. Illegal Immigrants in U.S./Mexico Border Counties: The Costs for Law Enforcement, Criminal Justice, and Emergency Medical Services (report prepared for the United States/Mexico Border Counties Coalition, February 2001). That report included costs incurred by the offices of the sheriff, the marshal, the district attorney, the public defender, the superior court, the medical examiner, and probation and juvenile services. It did not include activities related to border enforcement.

${ }^{177}$ Id.
} 
that the economic benefit of illegal immigration has not outweighed the burden of their social services needs. ${ }^{178}$ For decades, most Americans have been challenged to accept illegal immigration as a way of life in the United States. Clinton campaigned on reducing illegal immigration in 1996, while immigration issues became a major national security priority for Bush following 9/11. However, what followed from both presidents seemed to be policies that did not effectively stop illegal migration into the United States. The result of many of Clinton and Bush's policies were more political rhetoric than substance because they did not permanently end illegal immigration.

Operation Gatekeeper: What went wrong?

Clinton was riding an immigration reform wave when he supported a measure by the U.S. Border Patrol to strengthen the U.S./Mexico border in the months before California voters approved Proposition 187, which was a referendum aimed at illegal immigration, in the November 1994 elections. Although a federal district court later ruled the California proposition unconstitutional, it illustrated the frustration of voters. One of the most crucial influences of Operation Gatekeeper was the political environment before and after it was introduced. The 1996 reelection campaign was focused on immigration, especially following Prop 187 just a few years prior. Clinton needed to win California in order to win the election, so introducing Operation Gatekeeper and the IIRIRA ensured just that. The only election defeat by Clinton was his reelection campaign in the Arkansas gubernational election of 1980, which came after he agreed to house Cuban refugees in

\footnotetext{
${ }^{178}$ Richwine, Jason, and Robert Rector. "The Fiscal Cost of Unlawful Immigrants and Amnesty to the U.S. Taxpayer.” The Heritage Foundation, May 6, 2013.

https://www.heritage.org/immigration/report/the-fiscal-cost-unlawful-immigrants-and-amnestythe-us-taxpayer.
} 
Arkansas after the Mariel boatlift. ${ }^{179}$ Thus, Clinton knew he need to have a strong presence on illegal immigration.

Operation Gatekeeper secured Congressional funding for the first 14 miles of wall construction from the Pacific Ocean and doubling the number of border patrol agents. But all this did was shift illegal immigrant crossing routes east into more dangerous terrain. While Operation Gatekeeper was not considered a lasting success, it did prove that a durable wall along with tougher border security policies prevented illegal immigrants from easily crossing into the United States.

After building the wall, San Diego saw a decrease from 40 percent of illegal immigration crossings drop to ten percent by 2000 . The first 14 miles of wall construction was such a success for Operation Gatekeeper proponents that even California U.S. Senator Dianne Feinstein remarked in 1999 how "Operation Gatekeeper has really been an unprecedented success. What it tells me is it's a myth that the border can't be enforced. It can be enforced." ${ }^{180}$ Robert Back, the top policy official for the INS in 1999 said, "It is wonderful progress in an area where, frankly, most of us never really believed that government intervention like this would work."181

However, Operation Gatekeeper should not be viewed as a success but instead a missed opportunity because President Clinton and Congress were shortsighted by not constructing a durable wall the entire 1,954-mile length of the southern border with Mexico. At that time, it was mutually agreed by both Democrats and Republicans that the United States should strengthen their border policies. But only 14 miles of wall

${ }^{179}$ Freidel, Frank, and Hugh Sidey. "William J. Clinton." The White House. White House Historical Association, 2006. https://www.whitehouse.gov/about-the-whitehouse/presidents/william-j-clinton/.

${ }^{180}$ U.S. Senator Dianne Feinstein, Address to Congress, 1999.

${ }^{181}$ Robert Back, Interview, New York Times, 1999. 
construction was hardly a reasonable solution to stop illegal crossings. As the problem was pushed into Arizona, New Mexico, and Texas, the number of illegal immigrants continued to rise as did crime and drug trafficking along the border. Even the U.S. General Accounting Office concluded that "although illegal alien apprehension has shifted, there is no clear indication that overall illegal entry into the United States along the Southwest border has declined." ${ }^{182}$

One of the most crucial parts of Operation Gatekeeper was the political environment before and after it was introduced. The 1996 reelection campaign was focused on immigration, especially following Prop 187 just a few years prior. Clinton needed to win California in order to win the election, so introducing Operation Gatekeeper and the IIRIRA ensured just that. The only election defeat by Clinton was his reelection campaign in the Arkansas gubernational election of 1980, which came after he agreed to house Cuban refugees in Arkansas after the Mariel boatlift. ${ }^{183}$ Thus Clinton knew better this time, and wanted to have a strong presence on illegal immigration.

Although it was politically advantageous and cheaper to simply build a wall for the first 14 miles, Clinton actually perpetrated a lasting disservice to Americans by not supporting wall construction the entire length of the southern border.

\section{Illegal Immigration Reform and Immigrant Responsibility Act of 1999}

Operation Gatekeeper was not the only illegal immigration policy that should be cited as a missed opportunity. The Illegal Immigration Reform and Immigrant Responsibility Act of 1996 ought to be viewed as an even bigger bust than Operation Gatekeeper. Even

\footnotetext{
${ }^{182}$ United States. General Accounting Office. INS's Southwest Border Strategy: Resource and Impact Issues Remain After Seven Years. Washington D.C., 2001.

183 "1982 Arkansas Elections". Arkansas Secretary of State. May 1983. Retrieved May 01, 2019.
} 
though there were important parts of the IIRIRA that can be viewed as a stepping-stone to further reform, as a whole, its goal and mission to prevent illegal immigration were not achieved. Although the IIRIRA increased funding to the border, it was only for the 14mile wall that was built from Operation Gatekeeper. ${ }^{184}$ It is somewhat surprising that President Clinton and Congress did not expand wall construction after realizing how successfully Operation Gatekeeper shifted the paths of illegal immigrants. While increased wall construction would have been effective, the IIRIRA failed because implementation of the bill was slow due to a slow legal system that detained illegal immigrants for lengthy periods before they had a detention hearing.

Similarly to Operation Gatekeeper, there were alternate motives behind Clintons support of the IIRIRA. The intention of the Clinton Administration in signing it was due to the political environment of the time. Clinton's intention to ensure he received the votes from Californians encouraged his support of the legislation. As senior advisor to President Clinton, Rahm Emanuel, put it, "The illegal immigration legislation provides that same opportunity; now that the legislation is passed, we can build up a strong Administration record on immigration."

Immigrants cross over the southern border of the United States illegally for work opportunities or to flee dangerous conditions in their home country. One of the ways that the United States has tried to discourage illegal immigrants from entering to work is to fine employers who hire them. In 1986, Congress introduced employer sanctions that

\footnotetext{
${ }^{184}$ H.R. 2202, 104th Cong. (September 24, 1996) (enacted).

${ }^{185}$ Senior Advisor Rahm Emanuel to President Bill Clinton, November 20, 1996, Office of The President, Domestic Policy, William J. Clinton Presidential Library. Records Concerning Rahm Emanuel, Special Assistant to the President, 1993-1999. Box 5.
} 
fined employers if they hired illegal immigrants. ${ }^{186}$ The idea behind a steep fine was that if there were no jobs in the United States for illegal immigrants, they would be discouraged from migrating. However, in 2002, the INS only issued 53 notices of intent to fine employers. ${ }^{187}$ In years prior to 1996 , the INS routinely issued more than 1,000 Notices of Intent to Fine to employers per year. ${ }^{188}$ The IIRIRA did not address this concern. It did increase the involvement of illegal immigrants with the criminal justice system, which proved to be both beneficial yet detrimental. Another issue that has been brought into question by politicians and legal scholars: Should illegal immigrants be treated in the legal system equal to American citizens? The IIRIRA allocated $\$ 670$ million to create detention centers where illegal immigrants would be housed before their hearing. ${ }^{189}$ This slow judicial deportation process has cost United States taxpayers hundreds of millions of dollars during the past twenty years.

Another failed implementation of the IIRIRA were the mandatory detention rules. Misinterpretation of the policies led to failed implementation. The detention rules stated that INS was to take aliens who are deportable on specified criminal grounds into custody "when the alien is released," and it limits the circumstances in which the INS could release the illegal immigrant. ${ }^{190}$ The INS interpreted this rule by taking all illegal immigrants into custody for crimes they committed in the past, even if they had served their sentences and were released, and rejected requests for discretionary release, saying

\footnotetext{
${ }^{186}$ Immigration Reform and Control Act of 1986, Pub. L. 99-603, 100 Stat. 3359 (1996) (codified as amended at 8 U.S.C.

${ }^{187}$ U.S. Department of Homeland Security, Yearbook of Immigration Statistics , 2002, at http://uscis.gov/graphics/shared/aboutus/statistics/yearbook2002.pdf.

${ }^{188}$ U.S. Immigration and Naturalization Services, Statistical Yearbook of the Immigration and Naturalization Service, 1997, http://uscis.gov/graphics/shared/aboutus/statistics/1997YB.pdf.

${ }^{189}$ IIRIRA, supra note 101. ${ }^{190} \mathrm{Id}$.
} 
that the IIRIRA took away their power to do so. The next problem was the failure of the IIRIRA to develop a sound deportation immigration policy: Why should an immigrant who is in the United States illegally be released back into the United States? Policies like this allowed the number of aliens to skyrocket during the Clinton and Bush presidencies. If the IIRIRA had allowed for an illegal immigrant to be detained and deported through a swift hearing process, then it would have been more effective in stopping illegal immigration. However, one important benefit of the IIRIRA was the increase in border security funding and the increase of border patrol agents.

Immigration Policies 2000-Pre 9/11 2001

When Texas governor and Republican Party candidate George W. Bush was elected president in late 2000, it was expected that the relationship between the United States and Mexico would improve. Bush had realized in the months leading up to the November election that he would have to garner a larger share of the Latino vote than most Republican candidates to win the presidency, which proved to be true with his slim victory in Florida to beat Vice President Al Gore. Rather than supporting further wall construction in the 2000 presidential campaign to combat the continued rise in illegal immigration during Clinton's presidency, candidate Bush backed off any support for wall construction as to ensure that it did not become a campaign issue. It worked and Bush was narrowly elected president by the Electoral College despite losing the popular vote.

President Bush supported immigration policies in the seven months prior to $9 / 11$ that were aimed at making the legalization process more efficient. What President Bush failed to understand was that the real danger in not securing the border was that it 
immediately led to increased crime and drug trafficking. Even though every year during Clinton's presidency had seen a drastic increase in the number of illegal crossings into the United States, it took the terrorist attacks of 9/11 for Bush to reverse much of his campaign rhetoric to champion a strong national security position that did change immigration policies at all United States borders.

In the early months of his presidency prior to $9 / 11$, Bush had been focused on improving relationships between Mexico and the United States through meetings with Mexican President Fox rather than forcing a hardliner approach on illegal immigration. In fact, it was during this time that Bush supported the first unsuccessful attempt to create the DREAM Act for children who had illegally entered the United States with their parents.

Without the events of 9/11, it is difficult to speculate how Bush would have resolved the increasing numbers of illegal immigrants migrating into the United States. So how did 9/11 change Bush's rhetoric? It transformed Bush's previous declaration, "For those who want to wall off Mexico from Texas, I say you're dead wrong" to "I was the governor of a state that has a twelve-hundred mile border with Mexico. So I know how difficult it is to enforce the border, and how important it is." ${ }^{191}$ In the years following 9/11, Bush had several missed opportunities to propose legislation to extend wall construction and deportation reform that would have drastically decreased illegal immigration.

\footnotetext{
${ }^{191}$ President George W. Bush, “Addressing the Nation on Immigration Reform” (May 15, 2006), Government Publishing Office, https://www.govinfo.gov/content/pkg/PPP-2006-book1/pdf/PPP2006-book1-doc-pg928.pdf
} 


\section{Anti-Terrorism Act of 2001 and the Patriot Act}

In the month following the September 11 attacks, the Anti-Terrorism Act of 2001 was submitted to Congress and was soon followed by the PATRIOT Act. The terrorism of 9/11 certainly brought the issue of illegal crossings into the United States to the forefront of Bush's new policies. Illegal immigration now became his number one domestic priority. The PATRIOT Act was one of the most highly-criticized and debated laws that Bush introduced. There were many questions about constitutional infringements, particularly sections of the Patriot Act that related to illegal immigration from Mexico. One of the most controversial parts, Section 412, directly impacted illegal immigrants because the section allowed for indefinite detention even if they were not terrorists. ${ }^{192}$ However, the section also allowed for the release of illegal immigrants into the United States if their home country did not accept them. This set a precedent that reduced penalties if illegal immigrants could not be immediately deported. However, the PATRIOT Act said that when an immigrant was not certified, meaning they did not pose a national security risk, they were released into the United States population. This was a perfect example of a failed immigration policy.

The release of illegal immigrants into the United States is one of the reasons why there was an increase in illegal immigration from 2000 to 2005. The PATRIOT Act became a constitutional conflict that could not force immediate deportation due to habeas corpus and judicial review issues. But the fact remained that illegal immigration cost Americans hundreds of millions of dollars with a policy that originated with the Bush administration. It compromised the federal budget because illegal immigrants were given equal treatment to legal Americans and residents. The Government Accountability Office

192 The Patriot Act, supra note 139. 
released a report that examined the criminal histories of 55,322 aliens that "entered the country illegally and were still illegally in the country at the time of their incarceration in federal or state prison or local jail during fiscal year 2003. ${ }^{, 193}$ In this report, those 55,322 illegal immigrants had been arrested 459,614 times, which is an average of 8.3 arrests per person, and had committed close to 700,000 criminal offenses, which is an average of 12.7 offenses per person. ${ }^{194}$ Bush should have developed a policy that was constitutional to permit the immediate deportation of illegal immigrants once they were taken into custody.

Similar to Clinton, Bush felt pressure by his party to be viewed as a strong national security president. Illegal immigration is a national security issue because it can not be known if a possible terrorist enters through the border if left unsecured. Immediately following 9/11, Bush was expected to support all legislation that was tough on national security, which would include securing the nation's borders. At the time, there was support by both parties to do so. This window of opportunity is why the legislation that was passed can be viewed as a failure, because this was the opportunity to finally secure the southern border with Mexico.

\section{The Homeland Security Act of 2002}

The Homeland Security Act was the largest and most complex reorganization of the federal government since the Department of Defense was created after World War II. It combined 22 different agencies with 170,000 federal employees to create a new federal bureaucracy. The Homeland Security Act directly affected illegal immigration reform

\footnotetext{
${ }^{193}$ United States. General Accounting Office. Information on Certain Illegal Aliens Arrested in the United States. Washington D.C. 9 May 2005.

${ }^{194}$ Id.
} 
because it eliminated the Immigration Naturalization Service and the U.S. Customs Service was reorganized to become the Bureau of Customs and Border Protection (CBP). Despite this departmental reform, the number of illegal immigrant crossings continued to increase during the Bush years.

Was the consolidation of the U.S. Customs Service into the Department of Homeland Security the best solution to reform illegal immigration at the southern border? The Department of Homeland Security became the third largest federal department, growing the number of federal employees from 170,000 to $240,000 .{ }^{195}$ The lack of a clear mission complicated the role of the DHS in the illegal immigration issue. The counterterrorism mission following 9/11 caused more confusion for the border patrol agency. Prior to the terrorist attacks, the Customs Service was focused on drug busts and preventing illegal immigrants from entering. Afterwards, the mission changed to counterterrorism. This priority change made the CBP less efficient in preventing illegal immigration because they were now tasked with searching for possible terrorists.

The DHS budget grew from $\$ 27$ billion in 2003 to $\$ 57$ billion by $2007 .{ }^{196} \mathrm{An}$ example of one of the failed DHS projects was the Secure Border Initiative Network virtual fence project for a 53-mile portion of the Arizona-Mexico border. The CBP spent $\$ 1$ billion on this project before it was abandoned in $2011 .{ }^{197}$ If the CBP had been organized into its own independent department along with ICE, similar to how the INS regulated immigration for 125 years, it would have developed better immigration policies

195 The Homeland Security Act of 2002, Pub. L. 107-296, 107th Congress, 2nd sess., (November 25, 2002), www.dhs.gov/xlibrary/assets/hr_5005_enr.pdf.

${ }^{196}$ Department of Homeland Security. DHS Annual Financial Report. Washington, DC, 2007.

${ }^{197}$ United States. United States Government Accountability Office. SECURE BORDER INITIATIVE: DHS Has Faced Challenges Deploying Technology and Fencing Along the Southwest Border. Richard M. Stana. Statement for the Record to the Committee on Homeland Security and Governmental Affairs, U.S. Senate 
at the border. The complexities of illegal immigration during the Bush administration were worthy of an independent agency to be more effective to implement presidential policies and congressional measures. It also compromised CBP when it had to compete for funding against FEMA, TSA, ICE, and the Secret Service.

\section{$\underline{\text { Secure Fence Act of } 2006}$}

The Secure Fence Act of 2006 was the first time President Bush supported the construction of a physical wall along the southern border. From 2005 until 2010, CBP increased the wall from 119 miles to 654 miles. ${ }^{198}$ This is misleading because 300 miles was vehicle fencing, meaning an individual can easily walk through it. However, the success from this increase proved that a completed wall from the Pacific Ocean to the Gulf of Mexico would significantly reduce the number of illegal immigrant crossings. Illegal immigrants are only able to enter the United States through sections that do not have a wall with surveillance.

The major failure in the Secure Fence Act of 2006 is the same failure that was prevalent with Operation Gatekeeper: it did not complete the task of building a wall along the entire southern border. While a finished wall itself would not have been the total answer without major increases in border agents and technology, it would have been effective in decreasing the number of illegal immigrants. If it worked in San Diego during Operation Gatekeeper, what would have prevented it from working along the Arizona-Mexico border? The most reasonable answer is the terrain, but different types of barriers would have prevented entry. The best way to lower the number of illegal immigrants in the United States is to prevent them from entering the country in the first

198 "Fact Sheet: The Secure Fence Act of 2006". The White House. 
place. Therefore, securing the entire southern border should have been Bush's top priority, followed by a more effective deportation process that was constitutional.

\section{Illegal Immigration - Final Thoughts}

Both Clinton and Bush failed during their presidencies to promote effective policies and laws that would have had long-term benefits to stop the increase of illegal immigrant crossings into the United States. Both presidents failed to take advantage of several political, economic, and social opportunities to extend the wall east to the Gulf of Mexico and support the adoption of effective laws by Congress that would have prudently solved many immigration problems. Both presidents simply did not want to risk their presidencies by recognizing illegal immigration for the serious problem that it has become in the 21 st century. Therefore, it can certainly be argued that these presidents abdicated presidential leadership by not resolving the core issues of illegal immigration during their terms.

Given the historical background and analysis of the immigration issue presented to the reader in this thesis, it is appropriate for this writer to present my perspectives to the questions offered in the introduction: Why didn't the United States Congress and President Clinton pass laws and implement strong policies and/or Executive Orders that could have helped to prevent today's political division in American society? And, how did President Bush fail to take advantage of the 9/11 window of opportunity to fully strengthen United States immigration laws that would have permanently strengthened America's southern borders with Mexico? 
To answer the first question, which essentially asks: Why didn't President Clinton pass stronger illegal immigration policies, one needs to understand the political realities of Clinton's eight years in office. To be fair, Operation Gatekeeper was the first immigration law of its kind. It was the first time illegal immigrant routes were disrupted, and the first time a policy aimed at strengthening border security was implemented since President Ronald Reagan's immigration reforms of 1986. However, it was naïve for Clinton, Congress, and even the border states who played a role in its design to believe illegal immigrants would simply give up because the terrain was tougher to enter the United States. These illegal immigrants were knowingly risking their lives to cross anywhere along the border, and many had previously been caught and deported several times. Operation Gatekeeper and its successor, the Illegal Immigration Reform and Immigrant Responsibility Act of 1996, were flawed from practically day one because crossings numbers of illegal immigrants never decreased. Clinton ought to have issued an executive order and/or Congress should have enacted laws to expand the wall/surveillance technology to the impacted entry points along the southern border.

Why did President Bush fail to take advantage of the 9/11 window of opportunity? Bush felt the pressure to do something drastic following the attacks on American soil, but ended up doing too much that was too controversial and even unconstitutional. Creating the Department of Homeland only caused more confusion because it was a massive bureaucratic department that was slow to get things done. Another factor that slowed Bush's illegal immigration reform was his reelection campaign in 2004. Bush had received more Latino votes in the 2000 election than the previous Republican nominee. How could he sustain this if he proposed strict border 
policies that might anger Latino voters? This concern, however real, caused Bush to be ineffective on illegal immigration reform during his presidency.

It is clear that both presidents faced political pressures during their presidency. For Clinton, the reelection campaign of 1996 influenced his stance on illegal immigration, and was one of the main reasons why he supported Operation Gatekeeper and the IIRIRA. For Bush, the political pressure to propose strong national security measures following $9 / 11$ influenced his stance on illegal immigration. Although no known domestic terrorists have entered through the southern border, crime from illegal immigrants entering the country is a national security matter. The terrorists who committed the crimes on $9 / 11$ were the first to find the loopholes in the visa programs in the United States, so who is to say that if the southern border is left unsecured, that a future terrorist will not enter the country? If securing the border will save Americans' lives, then it is critical the President ensures that the border is fortified. This means that Bush was influenced by the domestic terror attacks on $9 / 11$ to support legislation that would secure the southern border. The arguments presented illustrates why both presidents failed to take advantage of this window of opportunity to do so.

So what immigration laws and policies should Congress and Presidents Clinton and Bush have passed and implemented that most Americans would have supported to provide strong border security along the southern border?

First, Clinton ought to have developed administration policies and proposals to Congress that were more comprehensive than Operation Gatekeeper and the Illegal Immigration and Immigrant Responsibility Act of 1996. If Clinton had been unable to get cooperation from Congress to support tougher immigration measures, then he should 
have sought support from Americans through the national media and television/radio broadcasts. His failure to promote a wall the entire length of the southern border when both political parties agreed on most aspects of immigration reform showed a lack of presidential leadership. It was probably the best opportunity during the past 25 years that Congress could have agreed on immigration reform.

Second, Bush should not have overreached by combining 22 agencies in establishing the Department of Homeland Security immediately following 9/11. Initially, it diverted too many resources away from illegal immigration efforts with its large bureaucracy. Its primary focus, of course, was combating homeland terrorism not illegal immigration issues from non-terrorists.

Third, Bush should have been more determined following 9/11 to construct a wall along the entire southern border as part of his comprehensive national security plan. By the time Bush supported the Secure Fence Act of 2006, he was another lame-duck president who had also missed a golden opportunity to reform illegal immigration. Bush could not even get support from his own Republican Party to pass guest worker immigration reform that would have eased illegal migration into the United States.

Presidents Clinton and Bush did not take advantage of their opportunities to permanently solve illegal immigration problems by building a 1,954-mile wall along the entire United States-Mexico border. If either president had demonstrated strong leadership to follow through with their campaign rhetoric on immigration, it is possible that the United States would not be mired in illegal immigration issues today. Instead, illegal immigration is among one of the policy issues that is most divisive within American politics today. 


\section{Bibliography}

"1982 Arkansas Elections". Arkansas Secretary of State. May 1983. Retrieved May 01, 2019.

2016 Yearbook of Immigration Statistics. "Table 39. Aliens Removed Or Returned: Fiscal Years 1892 To 2016." Department of Homeland Security. November 30, 2017. https://www.dhs.gov/immigration-statistics/yearbook/2016/table39. (Accessed March 03, 2019).

Aas, Katja Franko., and Mary Bosworth. The Borders of Punishment: Migration, Citizenship, and Social Exclusion. Oxford: Oxford University Press, 2013.

ABC News, This Week with David Brinkley, 20 June 1993

Administration's Draft Anti-Terrorism Act of 2001, 107th Cong., 1st sess., September 24, 2001, http://commdocs.house.gov/committees/judiciary/hju75288.000/hju75288_0f.htm

Andreas, Peter. Border Games: Policing the U.S.-Mexico Divide. Ithaca: Cornell University Press, 2009.

Back, Robert. Interview, New York Times, 1999.

Beasley, Vanessa B. Who Belongs in America? Presidents, Rhetoric, and Immigration. College Station: Texas A\&M University Press, 2006.

Birns, Larry. "Broader Border?" Council on Hemispheric Affairs. Center for Strategic and International Studies.

Brook, D., \& Cynthia L. King. (2007). Civil Service Reform as National Security: The Homeland Security Act of 2002. Public Administration Review, 67(3), 399-407. Retrieved from http://www.jstor.org.libproxy.chapman.edu/stable/4624582

Buffett, Howard G. Our 50 State Border Crisis: How the Mexican Border Fuels the Drug Epidemic across America. Place of Publication Not Identified: Hachette Books, 2019.

Bush, George W., Renewing America's Purpose: The Policy Addresses of George W. Bush, 1999-2000 (Washington, DC: Republican National Committee. 2000), 19597.

Bush, George W., "Addressing the Nation on Immigration Reform” (May 15, 2006), Government Publishing Office, https:/www.govinfo.gov/content/pkg/PPP-2006book1/pdf/PPP-2006-book1-doc-pg928.pdf 
Camarota, Steven A., and Rosemary Jenks. "Implementation of the Enhanced Border Security and Visa Entry Reform Act of 2002." Center for Immigration Studies. December 1, 2003. https://cis.org/Report/Implementation-Enhanced-BorderSecurity-and-Visa-Entry-Reform-Act-2002.

Congressional Budget Office. The Impact of Unauthorized Immigrants on the Budgets of State and Local Governments, (2007).

https://www.cbo.gov/sites/default/files/110th-congress-2007-2008/reports/12-6immigration.pdf.

Conover, Ted. Coyotes: A Journey across Borders with America's Illegal Migrants. New York: Vintage Books, 2006. Page 2

"Deaths in World Trade Center Terrorist Attacks --- New York City, 2001." Centers for Disease Control and Prevention. Department of Health and Human Services, September 9, 2002.

https://www.cdc.gov/mmwr/preview/mmwrhtml/mm51SPa6.htm.

"Definition of Terms" Department of Homeland Security. https://www.dhs.gov/immigration-statistics/data-standards-anddefinitions/definition-terms\#18 (Accessed February 25, 2019).

DeSipio, Louis. 1996. Counting on the Latino Vote. Charlottesville: University of Virginia Press.

Doty, Roxanne Lynn. The Law into Their Own Hands: Immigration and the Politics of Exceptionalism. Tucson: Univ. of Arizona Press, 2009. Page 13.

Elections, Division office. "November 7, 2000 General Election". results.elections.myflorida.com. Retrieved 2019-03-10.

Enhanced Border Security and Visa Entry Reform Act of 2002, H.R. 3525. Pub. L. No. 107-173, 107th Cong., 2nd sess. (March 12, 2002).

Eschbach, Karl, et al. "Death at the Border:' International Migration Review 33.2 (1999): 430-54. Data from the Mexican Ministry of Foreign Relations

Eschbach, Karl. Deaths During Undocumented Migration: Trends and Policy Implications in the New Era of Homeland Security, Presentation Before the Twenty-Sixth Annual National Legal Conference on Immigration and Refugee Policy (Apr. 2003), in 26 IN DEFENSE OF THE ALIEN, at 37-52, 41, http://www.uh.edu/cir/Deathsduringmigr ation.pdf.

Espenshade, Thomas J., Jessica L. Baraka, and Gregory A. Huber. "Implications of the 1996 Welfare and Immigration Reform Acts for US Immigration." Population and Development Review 23, no. 4 (1997): 769-801. doi:10.2307/2137379. 
"Fact Sheet: The Secure Fence Act of 2006". The White House.

Freidel, Frank, and Hugh Sidey. "William J. Clinton.” The White House. White House Historical Association, 2006. https://www.whitehouse.gov/about-the-whitehouse/presidents/william-j-clinton/.

"General Election - Statement of Vote, November 8, 1994", California Secretary of State, statistical data, accessed March 3, 2019, https://www.sos.ca.gov/elections/prior-elections/statewide-election-results/generalelection-november-8-1994/statement-vote/\#ssov

“Grandfather Clause.” Legal Information Institute. Cornell Law School, June 22, 2015. https://www.law.cornell.edu/wex/grandfather_clause.

Gutiérrez, David. Walls and Mirrors: Mexican Americans, Mexican Immigrants, and the Politics of Ethnicity. Berkeley: University of California Press, 2007.

"Half an Enchilada: Mexico and the United States." The Economist, January 23, 2003.

Hedegaard H, Miniño AM, Warner M. Drug overdose deaths in the United States, 1999 2017. NCHS Data Brief, no 329. Hyattsville, MD: National Center for Health Statistics. 2018.

Hinkes, Madeline, "Migrant Deaths Along the California-Mexico Border: An Anthropological Perspective," Journal Of Forensic Sciences 53, no. 1 (January 2008): 16.

Homeland Security Act of 2002, Pub. L. 107-296, 107th Congress, 2nd sess., (November 25, 2002), www.dhs.gov/xlibrary/assets/hr_5005_enr.pdf.

HR 1918, Student Adjustment Act of 2001,107th Cong., 1st session.

H.R. 2202, 104th Cong. (September 24, 1996) (enacted).

H.R. 2580, 89th Cong. (Jun $30^{\text {th }}$, 1968) (enacted).

"Illegal Alien Resident Population." Department of Homeland Security. https://www.dhs.gov/xlibrary/assets/statistics/illegal.pdf.

Immigration and Customs Enforcement. Fiscal Year 2017 ICE Enforcement and Removal Operations Report, Fiscal Year 2017 ICE Enforcement and Removal Operations Report.

https://www.ice.gov/sites/default/files/documents/Report/2017/iceEndOfYearFY20 17.pdf. 
Immigration Reform and Control Act of 1986, Pub. L. 99-603, 100 Stat. 3359 (1996) (codified as amended at 8 U.S.C.

Intelligence Reform and Terrorism Prevention Act of 2004, S. 2845, Pub. L. 108-458, 108th Cong., 2nd sess., (December 17, 2004), http://intelligence.senate.gov/laws/pl108-458.pdf.

Lerner, Michael A. Dry Manhattan: Prohibition in New York City. Cambridge, MA: Harvard University Press, 2008.

Ludden, Jennifer. "1965 Immigration Law Changed Face of America.” NPR. NPR, May 9, 2006. https://www.npr.org/templates/story/story.php?storyId=5391395.

Macías-Rojas, Patrisia. "Immigration and the War on Crime: Law and Order Politics and the Illegal Immigration Reform and Immigrant Responsibility Act of 1996." Journal on Migration and Human Security 6, no. 1 (2018): 1-25. doi:10.14240/jmhs.v6i1.110.

Martin, Susan. A Nation of Immigrants. Cambridge University Press, 2010.

Massey, Douglas S., Jorge Durand, and Nolan J. Malone. Beyond Smoke and Mirrors: Mexican Immigration in an Era of Economic Integration. New York: Russell Sage Foundation, 2003.

McDonnell, Patrick J. “Prop. 187 Found Unconstitutional by Federal Judge.” LA Times, November 15, 1997.

"Mexico Takes Problem of Migrant Workers to OAS Tribunal." Associated Press, February 24, 2003.

MGT of America, Medical Emergency: Costs of Uncompensated Care in Southwest Border Counties September 2002. www.bordercounties.org.

Miller, David. Strangers in Our Midst: The Political Philosophy of Immigration. Cambridge, MA: Harvard University Press, 2018.

Morris, Helen. 1997. "Zero Tolerance: The Increasing Criminalization of Immigration Law.” Interpreter Releases 74(33): 1317-26.

Myers, Deborah, and Demetrios G. Papademetriou, "The US-Mexico Immigration Relationship: Operating in a New Context by Setting the Stage," Foreign Affairs en Español, Spring 2002.

National Public Radio, Kaiser Family Foundation and the Harvard University Kennedy School of Government. 2001. http://www.kff.org/content/2001/3209/CivilLibertiesFinalSummary.pdf. 
Ngai, Mae M. Impossible Subjects: Illegal Aliens and the Making of Modern America. Princeton (N.J.): Princeton University Press, 2014.

"Our Mission." Department of Homeland Security. May 11, 2016. https://www.dhs.gov/our-mission.

Peters, Gerhard; Woolley, John T. "George W. Bush: "Statement on Signing the Intelligence Reform and Terrorism Prevention Act of 2005," December 17, 2005". The American Presidency Project. University of California - Santa Barbara.

Pistone, Michele R., and Schrag, Philip G. 1996. "The 1996 Immigration Act: Asylum and Expedited Removal: What the INS Should Do." Interpreter Releases 73: 156579.

Plyler v. Doe, 457 U.S. 202 (1982)

Portman, Rob. Congressman. "Homeland Security Legislation." Interview by Margaret Warner.

President Bill Clinton, Address Before a Joint Session of the Congress on the States of the Union (Address to Congress, Washington, DC, January 24, 1995), C-Span, https://www.c-span.org/video/?54050-1/1994-state-union-address.

Prop 187. 1994. (Passed).

Public Papers of the Presidents of the United States: Lyndon B. Johnson, 1965. Volume II, entry 546, pp. 1037-1040. Washington, D. C.: Government Printing Office, 1966.

"Radio: A Consumer Product and a Producer of Consumption." Radio: A Consumer Product and a Producer of Consumption. Library of Congress, 1995. http://lcweb2.loc.gov:8081/ammem/amrlhtml/inradio.html.

Richwine, Jason, and Robert Rector. "The Fiscal Cost of Unlawful Immigrants and Amnesty to the U.S. Taxpayer." The Heritage Foundation, May 6, 2013. https://www.heritage.org/immigration/report/the-fiscal-cost-unlawful-immigrantsand-amnesty-the-us-taxpayer.

Ross, Susan. In the Shadow of error: The Illusive First Amendment Rights of Aliens. 6 COMM. L. \& POL'Y 75 (2001)

Rosenblum, Marc R. US IMMIGRATION POLICY SINCE 9/11: Understanding the Stalemate over Comprehensive Immigration Reform. Report. Washington, D.C.: Migration Policy Institute, 2011. 
S. 1291, Development, Relief, and Education for Alien Minors Act, 107th Cong., 2nd sess.

Salant, Tanis. Illegal Immigrants in U.S./Mexico Border Counties: The Costs for Law Enforcement, Criminal Justice, and Emergency Medical Services. February 2001.

Scalia, John. 1996. Non-Citizens in the Federal Criminal Justice System, 1984-1994. Washington, DC: US Bureau of Justice Statistics.

Schmitt, Eric. "Bush Aides Weigh Legalizing Status of Mexicans in U.S.," The New York Times, July 15, 2001.

Senior Advisor Rahm Emanuel to President Bill Clinton, November 20, 1996, Office of The President, Domestic Policy, William J. Clinton Presidential Library. Records Concerning Rahm Emanuel, Special Assistant to the President, 1993-1999. Box 5.

Sinnar, S. (2003). Patriotic or Unconstitutional? The Mandatory Detention of Aliens under the USA Patriot Act. Stanford Law Review, 55(4), 1419-1456. Retrieved from http://www.jstor.org.libproxy.chapman.edu/stable/1229608

Siskin, Alison. Visa Waiver Program. Report no. RL32221. December 11, 2015. Accessed March 3, 2019. https://fas.org/sgp/crs/homesec/RL32221.pdf.

"Table 39. Aliens Removed Or Returned: Fiscal Years 1892 To 2016." Department of Homeland Security. November 30, 2017. Accessed March 03, 2019. https://www.dhs.gov/immigration-statistics/yearbook/2016/table39.

The Public Enemy . United States: Warner Brothers, 1931.

United States Border Patrol. Monthly Apprehensions (FY 2000 - FY 2018). U.S. Customs and Border Protection. Department of Homeland Security.

United States Border Patrol. Southwest Border Deaths By Fiscal Year. Raw data. Southwest Border Sectors.

United States Census Bureau. Population Distribution, Population Distribution, (2003). https://www.census.gov/population/www/cen2000/censusatlas/pdf/2 PopulationDistribution.pdf.

United States, Congress, U.S. Department of Commerce. "World War II: 70 Years On." World War II: 70 Years On.

United States. Department of Commerce. U.S. Census Bureau. Overview of Race and Hispanic Origin: 2010. 2011. 
United States. Department of Homeland Security. Customs and Border Protection. U.S. Border Patrol Fiscal Year Staffing Statistics (FY 1992 - FY 2018). U.S. Customs and Border Protection.

United States. Department of Homeland Security. DHS Annual Financial Report. Washington D.C. 2007.

United States. Department of Homeland Security. Office of Inspector General. The Visa Waiver Program. (2 November 2012). By Charles K. Edwards, Acting Inspector General. Accessed February 21, 2019. https://www.oig.dhs.gov/assets/Mgmt/2013/OIG_13-07_Nov12.pdf

United States. Department of Homeland Security, Yearbook of Immigration Statistics , 2002, at http://uscis.gov/graphics/shared/aboutus/statistics/yearbook2002.pdf.

United States. General Accounting Office. Information on Certain Illegal Aliens Arrested in the United States. Washington D.C. 9 May 2005.

United States. General Accounting Office. INS's Southwest Border Strategy: Resource and Impact Issues Remain After Seven Years. Washington D.C., 2001.

United States. General Accounting Office, Report to Congressional Committees, GAO/GGD-99-44, Illegal Immigration: Status of Southwest Border Strategy Implementation 21 fig.8 (1999), http://www.gao.gov/archive/1999/gg99044.pdf [hereinafter Southwest Border Strategy Implementation]. Other Sectors include El Centro, Yuma, Tuscan, Mafa, Del Rio, Laredo, and McAllen.

United States. General Government Division. General Accounting Office. Illegal Immigration: Status of Southwest Border Strategy Implementation. Washington D.C., 1999.

United States. Government Accountability Office. SECURE BORDER INITIATIVE: DHS Has Faced Challenges Deploying Technology and Fencing Along the Southwest Border. By Richard M. Stana. Statement for the Record to the Committee on Homeland Security and Governmental Affairs, U.S. Senate.

United States. Government Accountability Office. SOUTHWEST BORDER SECURITY Additional Actions Needed to Better Assess Fencing's Contributions to Operations and Provide Guidance for Identifying Capability Gaps. Report to Congressional Requesters. February 2017.

United States. Immigration and Naturalization Service. Office of Policy and Planning. Estimates of the Unauthorized Immigrant Population Residing in the United States. By Department of Homeland Security. Accessed February 20, 2019. https://www.dhs.gov/xlibrary/assets/statistics/publications/Ill Report 1211.pdf. 
United States. Immigration and Naturalization Services, Statistical Yearbook of the Immigration and Naturalization Service, 1997, http://uscis.gov/graphics/shared/aboutus/statistics/1997YB.pdf.

United States-Mexico Migration Panel, Mexico-US Migration: A Shared Responsibility (Washington, DC: Carnegie Endowment for International Peace, 2001), www.carnegieendowment.org/pdf/files/M\%20exicoReport2001.pdf.

United States-Mexico Statement, Monterrey, Mexico, March 22, 2002.

United States Senator Dianne Feinstein, Address to Congress, 1999.

Uniting and Strengthening America by Providing Appropriate Tools Required to Intercept and Obstruct Terrorism Act of 2001 (USA PATRIOT Act). Pub. L.No. 107-56. §§ 412. 201-25. 115 Stat. 272. 278-96. 350-52 (2001)

Urban Institute, Children of Immigrants: Facts and Figures (Washington, D.C.: Urban Institute, 2006); and Passel, Unauthorized Migrants.

USA PATRIOT Act of 2001, Pub. L. 107-56, 107th Cong., 1st sess., (October 26, 2001).

Walsh, Kenneth. “Broader Border?” U.S. News \& World Report 131, August 20, 2001. 